\title{
The Effect of Service Quality, Promotion on the Purchase Decision Guna Bhakti Credit and the Impact of the Service Government Employee (PNS) DKI
}

\author{
AsepZaenuddin \\ MercuBuana University \\ Jakarta, Indonesia
}

\author{
BarunaHadibrata \\ MercuBuana University \\ Jakarta, Indonesia
}

\begin{abstract}
This study aims to determine the effect of service quality, promotion on the decision to purchase credit for devotion (kgb) by pnsdki and its impact on the loyalty of pnsdki customers in rawamangun branches. This study uses a quantitative method and the sample is 189. The customers are civil servants credit for the service of Rawamangun branch. by using the convenience sampling method and the data obtained were analyzed using the SEM-LISREL application.The results of this study indicate that the $t$ test has a significant effect between service quality on purchasing decisions, promotions on purchasing decisions, purchasing decisions on customer loyalty, service quality on customer loyalty, promotions on customer loyalty.
\end{abstract}

Keywords:- Service Quality, Promotion, Purchasing Decisions, Customer Loyalty.

\section{INTRODUCTION}

The role of banks to advance the economy of a country is huge.Banking institutions are the core of a country's financial system, almost all sectors related to financial activities always require bank services. The bank is an intermediary for the wishes of the people, namely intermediaries for customers who have excess money and keep their money in the form of demand deposits, deposits, and savings. As well as serving the needs of money and serving the needs of the community through the provision of consumer credit or productive credit.

The financial sector plays a crucial role in promoting the economic growth of a country. More precisely, the financial sector is able to mobilize savings and channel it to the parties in need through lending. This will add to the investment and eventually accelerate the economic growth. One of the institutions in the financial sector is the banking institution. According to banking law No. 10 year 1998 Article 1 explained that the meaning of the bank is a business entity that raises funds from the community in the form of deposits and distributes to the community in the form of credit or other forms in order to improve the lives of many people.
Banking is one of the services industry that is currently experiencing fairly strict competition. In line with the competition, almost all banks provide convenience for each of its customers. Starting from the provision of products in the form of savings, Giro, deposits, and the provision of credit facilities, tailored to the needs of customers, to provide excellent service quality, and provide a compelling promission in accordance with the wishes of the current debtor, so the debtor can decide to buy.

Service quality is crucial in the banking business. In addition to offering a wide range of products, banking should also be able to provide good service from both physical and non-physical which is intended to increase the trust of customers who will save or apply for credit facilities at the bank. Customer service is important for the bank in order to provide satisfaction to the customer so that the customer still believes in the bank and minimize the customer move to another bank. The Prime service can only be understood from the customer's point of view so that the bank must formulate a prime service through the customer's viewpoint.

The customer can decide on a product or service, one of them by improving the quality of service. Customer attitude in receiving the product offered one of them is with a satisfactory form of service. A similar product will look different if the service provided is more satisfying to customers. Customers who originally just impressed to see the products that are offered change with product purchase behavior. A company including banks is required to maximize the quality of its services in order to create customer satisfaction and will materialize purchase decisions, so that the bank objectives can be achieved.

In the promotion the bank is required to promote its products and services that are owned either directly or indirectly. No promotion please do not let customers know the bank. Therefore, promotion is the most powerful tool to attract and retain its customers. One of the purposes of bank promotion is to inform the product offered and try to attract new potential customers. Then the promotion also serves to remind the customer of the product, the promotion also affects the customer to create a developer's decision. 
In practice there are at least four kinds of promotional means that can be used in promoting both the product and its services. First, promotion through advertising, both through sales (sales promotion), third is publicity and the fourth through personal sales (personal selling).

Consumer purchasing decisions are preceded by the desire to buy that arises because there are various influential factors such as good service quality and work motivation that continues to develop as desired, the information provided, and the benefits or benefits that can be obtained from the product or service. When consumers make a purchase, many situational factors can influence their purchasing decisions.

According to Peter-Olson in (MulyadiNitisusastro 2015: 195) asserted that consumer decision making is a process of interaction between affective attitudes, cognitive attitudes, behavioral attitudes with environmental factors by which humans exchange in all aspects of their lives. Cognitive attitudes reflect attitudes of understanding, affective attitudes reflect attitudes of beliefs and behavioral attitudes reflect attitudes of real action. The decision to buy or not buy is part of an element inherent in the individual consumer called behavior where he refers to tangible physical actions that can be seen and can be measured by others.

Customer behavior after making a purchase of a product is determined by the feelings of pleasure or disappointment someone who appears after comparing the perception or impression of the service is below expectations, the customer is not satisfied. But if the service exceeds expectations, the customer is very satisfied and happy and buys back. Loyalty is something that arises without coercion but arises by itself. According to Giffin quoted by Sangadji and Shopiah (2013: 104) states that: "Loyalty refers more to the form of behavior of decisionmaking units to make continuous purchases of goods or services of a selected company." With purchases made customers can continuously provide long-term benefits for the company.

According to Tjiptono (2016: 393) argues that: Customer loyalty is a customer's commitment to a brand, store, or supplier, based on a very positive attitude and reflected in consistent repurchases. So that the greater the needs, the fundamentally the greater the income the customer must receive to meet his needs. To meet the needs that are increasing and fast someone usually makes a sacrificial loan, after making the loan for the agreed credit period. Usually civil servants spend their salary on installment payments in banks and finance their living from allowances and credit disbursements. Product choices are strongly influenced by one's economic situation, economic conditions include the income that can be spent.
Civil Servants (PNS) is a State Apparatus Resource whose duty is to provide services to the community in a professional, honest, fair and equitable manner in the implementation of state, government and development tasks based on loyalty and adherence to Pancasila and the 1945 Constitution. Position and role Civil Servants in Indonesia are felt increasingly important to organize government and development in an effort to achieve national goals. Therefore, the administration of government requires people who are able to carry out their duties and responsibilities to participate in national development efforts (Thoha, 2008).

The regional government of the Special Capital City Region of Jakarta is the administration of government affairs by the regional government and the People's Representative Council of the Special Regional Capital City Region of Jakarta according to the principle of autonomy and assistance tasks with the principle of broadest autonomy in the system and principles of the unitary state of the Republic of Indonesia as referred to in the law the constitution of the Republic of Indonesia in 1945.

The identification of the problems of this research is 1 . The Quality of Banking Credit Services in Indonesia has increased every year from waiting for prospective borrowers to come to the bank at this time to pick up the ball directly to the prospective debtor until a quick credit analysis, according to banking regulations, 2. Credit promotions carried out by banks today are very diverse, ranging from very competitive interest rates between banks, discounted insurance costs, discounted provision fees and free administrative fees, and can even attract attractive souvenirs so as to provide appeal for civil servants to apply for loans to banking, 3. The decision to purchase Guna Bhakti Credit "bjb" bank at the Rawamangun Branch Office is influenced by good, fast and easy quality of service in the process of credit disbursement and the promotions given are very competitive and attractive such as mild interest rates and discounted credit costs in applying for loans, 4. Increasing civil servants turns out to also have an impact on increasing the lives of civil servants in fulfilling their needs so that many civil servants apply for loans that "SK" employee on banks with loans, also impacting on civil servants to work much better or motivated to work to pay loan installments banking. The creation of customer loyalty to the services provided by the current banking and ease in the process of borrowing money or applying for credit facilities back with a process that is not complicated so that many DKI civil servants apply for credit Top Up to banks with the aim to meet the needs of life or reduce nominal installments credit and extend the loan period.

The research problems are 1. Does the good quality of service provided by the employees of "BJB" Bank Rawamangun branch affect the decision to purchase "guna bhakti" credit? 2. Does the promotion of guna bhakti credit given by Rawamangun branch affects the decision to 
purchase "guna bhakti"credit?3.Does the good quality of service provided by the employees of the "BJB" Rawamangun branch bank can have an impact on the creation of customer loyaltyguna bhakti credit in the DKI civil servants? 4. Does the promotion stragety "guna bhakti" credit provided by "BJB"Rawamangun branch affect the creation of customer loyalty for "guna bhakti" credit to the DKI provincial government civil servants?5. Does the decision to purchase "guna bhakti" credit to the DKI provincial government civil servants at Rawamangun branch office can have an impact on customer loyalty?

The purpose of this study is 1 . Analyzing the effect of service quality on the decision to purchase "guna bhakti" credit by the civil servants in the Rawamangun branch office, 2. Analyzing the effect of promotion on the decision to purchase "guna bhakti" credit by the civil servants in the Rawamangun branch office, 3. Analyzing the effect of service quality on the creation of customer loyalty "guna bhakti" credit in the DKI provincial government civil servants in Rawamangun branch office, 4. Analyzing the effect of promotion on the creation of customer loyalty "guna bhakti" credit in the DKI provincial government civil servants in Rawamangun branch office, 5. Analyzing the influence of purchasing decisions of DKI civil srvants customer who already have "guna bhakti" credit in the "BJB" Rawamangun branch office who feel happy or vice versa so that it will impact the creation of customer loyalty.

The limitations of the problem of this research are 1. Research only on DKI Jakarta Provincial Civil Servants who have applied for "guna bhakti" credit at the "BJB" bank Rawamangun Branch Office, 2. Borrower data "guna bhakti" credit in the "BJB" bank East Jakarta Rawamangun Branch Office the last three years filed in 2017, 2018 and 2019 were taken from one of the portal website "bankbjb.co.id" and data directly from the "BJB" bank Rawamangun Branch Office.

\section{LITERATURE REVIEW}

\section{A. Bank}

According to Kasmir (2014: 14), bank is a business entity that collects funds from the public in the form of deposits and channel them back to the public in the form of credit and or other forms in order to improve the lives of many people. While the banking business includes three activities, namely raising funds, channeling funds, and providing other bank services:

\section{B. Credit}

According to Jopie Jusuf (2014), credit is the ability to carry out a purchase or make a loan with a promise, payment will be carried out at an agreed time period. The other meaning of credit is the provision of money or bills which can be equaled based on the agreement or agreement between the bank and other parties that require the borrower to carry out the amount of interest in return. In daily practice, credit loans are expressed in the form of written agreements both under the hand and materially. And as a security guarantee, the borrower will fulfill obligations and submit guarantees both material and non material.

\section{Service Quality}

According to Kotler (2016), service quality is any action or activity that can be offered by one party to another party, basically intangible and does not result in any ownership.

According to Wyock (in lovelock, 1988) quoted by FandyTjiptono (2016: 268) Service quality is the level of excellence (expected) expected and control over these advantages to meet consumer needs.

\section{Promotion}

According to RambatLupiyoadi (2015), promotion is one of the variables in the marketing mix that is very important to be carried out by companies in marketing service products. Promotional activities not only function as a communication tool between the company and consumers, but also as a tool to influence consumers in purchasing or using services in accordance with their wants and needs.

According to FandyTjiptono (2016), sales promotion is a direct form of persuasion through intensive use that can be arranged to stimulate product purchases immediately or increase the number of items customers buy.

\section{E. Purchace Decision}

Acording to Kotler and Armstrong (2014:158), Consumer buyer behavior refers to the buying behavior of final consumer individuals and households that buy goods and services for personal consumption.

According to Peter-Olson in (MulyadiNitisusastro 2012: 195), consumer decision making is a process of interaction between affective attitudes, cognitive attitudes, behavioral attitudes with environmental factors with which humans exchange in all aspects of their lives. Cognitive attitudes reflect attitudes of understanding, affective attitudes reflect attitudes of beliefs and behavioral attitudes reflect attitudes of real action. The decision to buy or not buy is part of an element inherent in the individual consumer called behavior where he refers to tangible physical actions that can be seen and can be measured by others.

\section{F. Customer Loyalty}

According to Kotler and Keller (2016:153), customer loyalty is a deeply held commitment to rebuy or repatronize a preffered a product or service in the future despite situational influences and marketing efforts having the potential to cause switching behavior. 
According to Tjiptono (2014: 393), customer loyalty is a customer commitment to a brand, store, or supplier, based on a very positive attitude and reflected in consistent repurchases.

\section{J. Framework}

The framework of thought in this quantitative study is made in the form of a comprehensive diagram of a collection of independent variables that have a derivative form of dimensions and indicators in full of the dependent variable to determine the clarity of the flow of research based on the theory previously described.

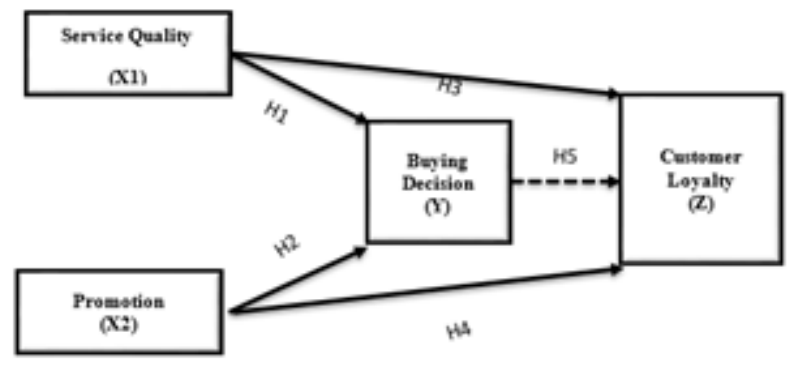

Fig 1:- Framework

\section{K. Hypothesis}

H1: Service quality has a positive effect on the decision to purchase "Guna Bhakti" credit in "BJB" bank Rawamangin Branch Office.

$\mathrm{H} 2$ :Promotion has a positive effect on the decision to purchase "Guna Bhakti" credit in "BJB" bank Rawamangin Branch Office.

H3: Service quality has a positive effect on customer loyalty "Guna Bhakti" credit in "BJB" bank Rawamangin Branch Office.

H4: Promotion has a positive effect on customer loyalty "Guna Bhakti" credit in "BJB" bank Rawamangin Branch Office.

H5: The purchase decision has a positive effect on customer loyalty "Guna Bhakti" credit in "BJB" bank Rawamangin Branch Office.

\section{METHODOLOGY}

This type of research used in this research is quantitative research with a descriptive approach. Quantitative research methods are one type of research whose specifications are systematic, planned and clearly structured from the beginning to the design of the research.

This study uses a descriptive approach with the aim of describing the object of research or research results.

To achieve the objectives of the hypothesis testing research it is necessary to use a statistical test using relevant software tools, namely the SEM compatible version in order to find out the positive influence on variables in this study such as service quality, promotion of the decision to purchase "Guna Bhakti" Credit and its impact on the Work Motivation DKI Civil Servantsat the "BJB" bankRawamangun Branch.

Based on the theoretical study described earlier, the operational variables in this study consist of three types, namely the independent variable, the intervening variable and the dependent variable. The variables in this study consisted of the independent variable (independent), then there are dimensions and indicators in detail as follows:

Table 1:- Operational Table

\begin{tabular}{|c|c|c|c|c|c|c|}
\hline $\begin{array}{l}\text { Variables and } \\
\text { Concepts }\end{array}$ & $\begin{array}{c}\text { Sub Variable } / \\
\text { Dimension }\end{array}$ & Indicator & Measurement & $\begin{array}{l}\text { Data } \\
\text { Type }\end{array}$ & $\begin{array}{r}\text { Data } \\
\text { Scale }\end{array}$ & Code \\
\hline & 1 Tangibles & $\begin{array}{l}1 \text { Facilities of } \\
\text { Physical } \\
\text { Building "BJB" } \\
\text { Bank } \\
\text { Rawamangun }\end{array}$ & $\begin{array}{l}1 \text { Level of } \\
\text { physical } \\
\text { facilities of } \\
\text { building "BJB" } \\
\text { Bank } \\
\text { Rawamangun }\end{array}$ & Ordinal & Likert & $\mathrm{K} 1$ \\
\hline & & $2 \begin{array}{c}\text { Employee } \\
\text { Equipment }\end{array}$ & $2 \begin{array}{l}\text { Employee } \\
\text { equipment level }\end{array}$ & Ordinal & Likert & K2 \\
\hline \multirow{7}{*}{$\begin{array}{c}\text { Service } \\
\text { Quality (X1) } \\
\text { Tjiptono } \\
\text { (2015) }\end{array}$} & & $\begin{array}{l}3 \text { Communication } \\
\text { Facilities }\end{array}$ & $\begin{array}{l}3 \text { Communication } \\
\text { facilities level }\end{array}$ & Ordinal & Likert & $\mathrm{K} 3$ \\
\hline & 2 Reliability & $\begin{array}{l}1 \text { Ability to serve } \\
\text { and satisfy } \\
\text { consumers }\end{array}$ & $\begin{array}{l}1 \text { Ability to serve } \\
\text { and satisfy } \\
\text { consumers level }\end{array}$ & Ordinal & Likert & K4 \\
\hline & $\begin{array}{l}3 \text { Responsiven } \\
\text { ess }\end{array}$ & $\begin{array}{l}1 \text { Customer } \\
\text { complaints and } \\
\text { wishes satiffy } \\
\text { customers }\end{array}$ & $\begin{array}{l}1 \text { Customer } \\
\text { complaints level }\end{array}$ & Ordinal & Likert & $\mathrm{K} 5$ \\
\hline & \multirow[t]{2}{*}{4 Assurance } & $\begin{array}{l}1 \text { Ability and } \\
\text { courtesy }\end{array}$ & $\begin{array}{l}1 \text { Ability and } \\
\text { courtesy level }\end{array}$ & Ordinal & Likert & $\mathrm{K} 6$ \\
\hline & & $\begin{array}{l}2 \text { Properties can } \\
\text { be believed }\end{array}$ & $\begin{array}{l}2 \text { Properties can } \\
\text { be believed } \\
\text { level }\end{array}$ & Ordinal & Likert & K 7 \\
\hline & \multirow[t]{2}{*}{5 Empaxy } & $\begin{array}{l}1 \text { Ease of applying } \\
\text { for "guna } \\
\text { bhakti" credit }\end{array}$ & $\begin{array}{l}1 \text { Ease of applying } \\
\text { for "guna } \\
\text { bhakti" credit } \\
\text { level }\end{array}$ & Ordinal & Likert & K8 \\
\hline & & $\begin{array}{l}2 \text { Good } \\
\text { communication } \\
\text { to consumers }\end{array}$ & $\begin{array}{l}2 \text { Good } \\
\text { communication } \\
\text { to consumers } \\
\text { level }\end{array}$ & Ordinal & Likert & $\mathrm{Kg}$ \\
\hline
\end{tabular}

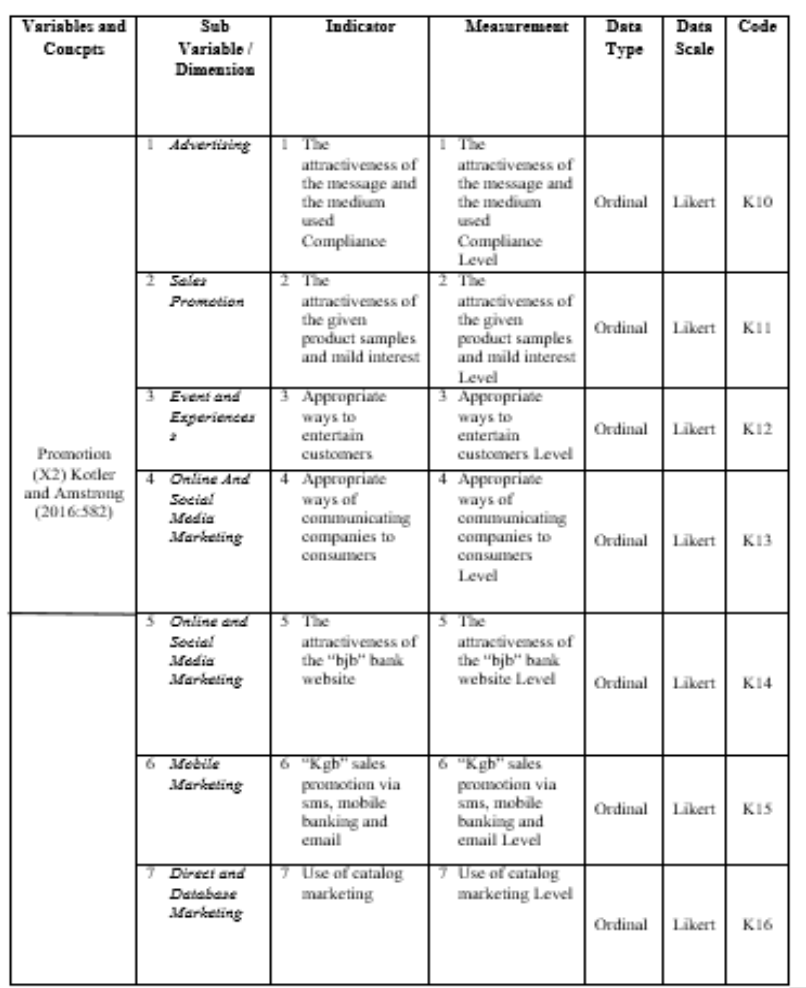




\begin{tabular}{|c|c|c|c|c|c|c|}
\hline $\begin{array}{l}\text { Variables and } \\
\text { Concepts }\end{array}$ & $\begin{array}{l}\text { Sub Variable / } \\
\text { Dimension }\end{array}$ & Indicator & Measurement & $\begin{array}{l}\text { Data } \\
\text { Type }\end{array}$ & $\begin{array}{l}\text { Data } \\
\text { Scale }\end{array}$ & Code \\
\hline & 1 Stay Faithful & $\begin{array}{l}1 \text { Consumers are } \\
\text { satisfied and the } \\
\text { tendency to } \\
\text { repurchase from } \\
\text { the same } \\
\text { manufacturer }\end{array}$ & $\begin{array}{l}1 \text { Consumer } \\
\text { satisfaction } \\
\text { level and } \\
\text { propensity to } \\
\text { repurchase from } \\
\text { the same } \\
\text { manufacturer }\end{array}$ & Ordinal & Likert & K23 \\
\hline & $\begin{array}{ll}2 & \text { Buy back } \\
\text { the } \\
\text { product } \\
\text { offered }\end{array}$ & $\begin{array}{l}2 \text { The desire to } \\
\text { repeat a good } \\
\text { experience }\end{array}$ & $\begin{array}{l}2 \text { The level of } \\
\text { desire to repeat } \\
\text { a good } \\
\text { experience }\end{array}$ & Ordinal & Likert & $\mathrm{K} 24$ \\
\hline \multirow[t]{3}{*}{$\begin{array}{l}\text { Customer } \\
\text { Loyalty } \\
\text { Kotler and } \\
\text { Keller (2016) }\end{array}$} & $\begin{array}{l}3 \text { Recommend } \\
\text { a product }\end{array}$ & $\begin{array}{l}3 \text { Offering to } \\
\text { others for } \\
\text { products that are } \\
\text { already used and } \\
\text { are satisfied }\end{array}$ & $\begin{array}{l}3 \text { The level of } \\
\text { offering to } \\
\text { others for } \\
\text { products that are } \\
\text { already used and } \\
\text { are satisfied }\end{array}$ & Ordinal & Likert & K25 \\
\hline & $\begin{array}{l}4 \text { Willing to } \\
\text { pay more }\end{array}$ & $\begin{array}{l}4 \text { Willing to pay } \\
\text { higher for the } \\
\text { best quality }\end{array}$ & $\begin{array}{l}4 \text { The rate is } \\
\text { willing to pay } \\
\text { higher for the } \\
\text { best quality }\end{array}$ & Ordinal & Likert & $\mathrm{K} 26$ \\
\hline & $\begin{array}{ll}5 & \text { Give } \\
& \text { feedback }\end{array}$ & $\begin{array}{l}5 \text { Give advice and } \\
\text { input as they } \\
\text { wish }\end{array}$ & $\begin{array}{l}5 \text { The level of } \\
\text { giving advice } \\
\text { and input as } \\
\text { they wish }\end{array}$ & Ordinal & Likert & K27 \\
\hline
\end{tabular}

\begin{tabular}{|c|c|c|c|c|c|c|}
\hline $\begin{array}{l}\text { Variables and } \\
\text { Concepts }\end{array}$ & $\begin{array}{l}\text { Sub Variable / } \\
\text { Dimension }\end{array}$ & Indicator & Measurement & $\begin{array}{l}\text { Data } \\
\text { Type }\end{array}$ & $\begin{array}{l}\text { Data } \\
\text { Scale }\end{array}$ & Code \\
\hline \multirow{6}{*}{$\begin{array}{c}\text { Buying } \\
\text { Decision }(\mathrm{Y}) \\
\text { Kotler and } \\
\text { Keller } \\
(2016: 195)\end{array}$} & $1 \begin{array}{l}\text { Product } \\
\text { choice }\end{array}$ & $\begin{array}{l}1 \text { "Guna Bhaltt" } \\
\text { Credit products } \\
\text { service are } \\
\text { needed by } \\
\text { consumers }\end{array}$ & $\begin{array}{l}1 \text { "Guna Bhalti" } \\
\text { Credit products } \\
\text { service are } \\
\text { needed by } \\
\text { consumers } \\
\text { Level }\end{array}$ & Ordinal & Likert & K17 \\
\hline & $2 \begin{array}{l}\text { Brand } \\
\text { choice }\end{array}$ & $\begin{array}{l}2 \text { Display brand of } \\
\text { a product }\end{array}$ & $\begin{array}{l}2 \text { The level of the } \\
\text { "BJB" bank } \\
\text { brand in "guna } \\
\text { bhalti" credit } \\
\text { product }\end{array}$ & Ordinal & Likert & K18 \\
\hline & $3 \begin{array}{l}\text { Dealer } \\
\text { choice }\end{array}$ & $\begin{array}{l}3 \text { The place or } \\
\text { location of the } \\
\text { "BJB" bank } \\
\text { Rawamangun }\end{array}$ & $\begin{array}{l}3 \text { The level of the } \\
\text { location of the } \\
\text { "BJB" bank } \\
\text { Ravamangun }\end{array}$ & Ordinal & Likert & K19 \\
\hline & $\begin{array}{l}4 \begin{array}{l}\text { Purchase } \\
\text { comount }\end{array} \\
\text { a }\end{array}$ & $\begin{array}{l}4 \text { Amount of } \\
\text { "guna bhalti" } \\
\text { credit limit } \\
\text { services } \\
\text { submitted }\end{array}$ & $\begin{array}{l}4 \text { The Level of } \\
\text { Amount of } \\
\text { "guna bhakti" } \\
\text { credit limit } \\
\text { services } \\
\text { submitted }\end{array}$ & Ordinal & Likert & $\mathrm{K} 20$ \\
\hline & 5 Purchase & $\begin{array}{l}5 \text { The right time } \\
\text { in the decision } \\
\text { to purchase } \\
\text { "guna bhakti" } \\
\text { credit }\end{array}$ & $\begin{array}{l}5 \text { The Level of the } \\
\text { right time in the } \\
\text { decision to } \\
\text { purchase "guna } \\
\text { bhakti" credit }\end{array}$ & Ordinal & Likert & $\mathrm{K} 21$ \\
\hline & $6 \begin{array}{l}\text { Payment } \\
\text { method. }\end{array}$ & $\begin{array}{l}6 \text { How to pay in } \\
\text { installments for } \\
\text { "Guna Bhakti" } \\
\text { Credit }\end{array}$ & $\begin{array}{l}6 \text { The level of } \\
\text { How to pay in } \\
\text { installments for } \\
\text { "Guna Bhalti" } \\
\text { Credit }\end{array}$ & Ordinal & Likert & $\mathrm{K} 22$ \\
\hline
\end{tabular}

The independent variable (free) in this study are Service Quality (X1) and Promotion (X2).

In this study the intervening variable is the Purchasing Decision (Y).

In this study the dependent variable that will be examined is Customer Loyalty $(\mathrm{Z})$.

In this study the variables were measured using instruments in the form of interviews, online questionnaires using Google forms that meet the Likert scale type statement and distributed to consumers using social media such as Whatsapp, Line Messenger.

The population used in this study is DKI Jakarta Civil Servants who have used or applied for the "Guna Bhakti" Credit facility at the "bjb" bank Rawamangun Branch.

The sampling criteria in this study were determined by researchers with those relevant to the object of the study, the Civil Servants of the Provincial Government of "DKI" who had applied for a loan to use "Bhakti Credit" at the "BJB" Bank Rawamangun Branch.

To get the number of samples in accordance with the criteria, the researcher with his judgment (judgment) determined the sample population from the number of DKI Civil Servant customers who had applied for a Credit for Bhakti in the last three years 2018, 2017 and 2019 with a total NOA of Managed of 4,269). According to Heir, et.al. (1998) in Supramono and Haryanto (2005), the sample size for the purposes of testing hypotheses using structural equation models (SEM) ranges from 100-200. This amount is obtained by calculating the number of samples with the formula $7 \mathrm{x}$ the number of indicators (Heir, 1995), meaning that in this study the sample amounted ( 7 x $27=189)$.

Thus the number of samples that will be used for this study is 189 DKI Jakarta Civil Servants who have used or applied for the "Guna Bhakti" Credit facility at the "BJB" bank Rawamangun Branch.

The types of data used in this study are as follows:

\section{a. Primary Data}

For this study the authors used primary data obtained from observations, and the distribution of online questionnaires using the Google form to civil servants who had applied for a loan for "GunaBhakti" Credit at the "BJB" Bank Rawamangun Branch Office

\section{b. Secondary Data}

Secondary data that I use is obtained from books, reports, journals, and so forth

Collecting data requires various data collection techniques. In this study used a combination of data collection techniques consisting of:

\section{1) Interview}

Interview was conducted through direct communication to obtain the required data specifically exploring primary and secondary data in the observation unit, namely a number of bank service customers using surveyors who had been trained in advance. Interviews were conducted with a questionnaire as a guide to ensure the objectivity of filling out the questionnaire.

\section{2) Questionnaire}

The questionnaire was used as a surveyor's guide in primary data collection, especially for respondents.

\section{3) Observation}

Observations are made by direct observation to get more accurate information about the variables studied and to obtain other information that has not been estimated before.

The purpose of this thesis is to find out whether the variable Quality of Promotion and Promotion has an 
influence on Purchasing Decisions and has an impact on Pnsdki Work Motivation. The analysis technique used in this study is to use Structural Equation Modeling (SEM).

Structural Equation Modeling is a statistical tool used to solve multilevel models simultaneously that cannot be solved by linear regression equations. "SEM"can also be considered as a combination of regression analysis and factor analysis. "SEM" can be used to solve equation models with more than one dependent variable and also the reciprocal influence (recursive). "SEM" is based on analysis of variance so as to provide a more accurate covariance matrix than linear regression analysis.Statistical programs that can be used to complete "SEM", for example Analysis Moment of Structure (AMOS) or LISREL.

Validity Test is intended to measure the quality of measuring instruments. A measuring instrument needs to be done to determine the accuracy and accuracy. This test is conducted to determine the research instrument in measuring the measured variables, so the measuring instrument is said to have high validity if it can carry out its measurement function. If the validity is known to be high then the measurement results will have a small error variant so that the data collected is accurate and reliable data.

To test the instrument's validity the steps that must be carried out are:

a) Identify operationally the concept to be measured.

b) Conducting a measurement scale trial on a number of respondents it is suggested that the number of respondents for the trial, a minimum of 30 people.

c) Prepare a tabulation table for answers.

d) Calculate the correlation of each statement with a total score using the product moment correlation technique formula as follows:

$$
\mathbf{r}_{\mathrm{xy}}=\frac{\mathrm{n} \Sigma\left(\mathrm{x}_{\mathrm{i}} \mathrm{y}\right)-\left(\sum \mathrm{X}_{\mathrm{i}}\right)(\Sigma \mathrm{Y})}{\sqrt{\left\{\mathrm{n} \Sigma \mathrm{X}_{\mathrm{i}}^{2}-\left(\sum \mathrm{X}_{\mathrm{i}}\right)^{2}\right\}\left\{\mathrm{n} \Sigma \mathrm{Y}^{2}-(\Sigma \mathrm{Y})^{2}\right\}}}
$$

Where $r_{x y}$ is the validity coefficient of the item sought, $\mathrm{X}$ is the item's score score and $\mathrm{Y}$ is the total question score. If $r_{x y}$ or $r$-count is greater or equal to $r$-table, then the question is considered valid (significant). Significant correlation numbers indicate that the measuring instrument is valid and feasible to be used in testing the research hypothesis.

Reliability Test is carried out on questions that are already valid to find out to what extent the measurement results remain consistent.Reliability Test is a measure of consistency of research instruments, the instrument is said to be reliable if the measuring instrument shows consistent results, so that this instrument can be used safely because it can work well at different times and conditions.For the construct reliability test determined by the formula (Hair 2003):

$$
\text { Construct }- \text { Reliability }=\frac{\left(\sum \text { Std L Loading }\right)^{2}}{\left(\sum \text { Std } \text { Loading }\right)^{2}+\sum \varepsilon j}
$$

Calculation The validity and reliability test uses the confirmatory factor analysis method, the calculations of which are simultaneously using the Structural Equation Model with the help of a computer software program LISREL.

Testing the hypothesis in this study using Structural Equation Modeling (SEM) or Structural Equation Modeling. "SEM" is basically a statistical technique used to test a series of relationships between several Unobservable variables that are formed from subvariables (indicators) or Observable variables that are analyzed using the LISREL program version 8.0 (Sumacher, Lomax: 2004; Ferdinand: 2005: 45).The purpose of this analysis is to explain the relationship of a set of variables with other variables. With this analysis, it can be seen how much influence each exogenous variable has on endogenous variables directly. The steps of data processing and analysis in SEM analysis are as follows:

a) Building a theory based model (Theoritical Base Model)

Determine the theoretical model, which is reflected in the framework of thought. Furthermore, on the basis of the "theoretical model", a path diagram can be developed.

In making a path diagram, the relationship between constructs is represented by arrows. A straight arrow shows a direct causal relationship from one construct to another. The construct in the path diagram is divided into two, namely Endogenous Variable and Exogenous Variable. Exogenous Variable is also known as independent variable while Endogenous Variable are dependent variable. Endogen construct Variable can predict other endogen construct variable. Service Quality and Promotion are independent variables. Purchase Decision $\left(\eta_{1}\right)$ is as an intermediate variable and the dependent variable is an antecedent that directly influences Work Motivation $\left(\eta_{2}\right)$ as a consequence (the dependent variable).

$$
\begin{aligned}
& \text { Where: } \\
& \xi_{1}=\text { Service Quality Latent Variable } \\
& \xi_{2}=\text { Promotional Latent Variable } \\
& \eta_{1}=\text { Latent Variable Purchasing Decision } \\
& \eta_{2}=\text { Latent Variables Work Motivation } \\
& \zeta=\text { Residual Factor }
\end{aligned}
$$


b. Make a path diagram to illustrate causal relationships and translate into structural equations and measurement equations (Structural and Measurement Equation).After the theoretical relationship is formed, another method that can describe this relationship is through a path diagram.

c. Choose the type of input matrix and determine the estimated model.

Structural equation models generally use the covariance matrix and correlation matrix as the basis for analysis or as input data. Individual observations can be input into the program but the observations are converted into one or two types of matrices before estimation.

\section{d. Choose the type of input matrix and determine the estimated model.}

Structural equation models generally use the covariance matrix and correlation matrix as the basis for analysis or as input data. Individual observations can be input into the program but the observations are converted into one or two types of matrices before estimation.

\section{e. Check the model match results}

The purpose of SEM is to test whether the model proposed in the path diagram (theoretical model) is suitable, fit or not with data. Evaluation of the model is carried out as a whole (overall test). Chi-Square statistics can be used to test the suitability of the model inferentially with a hypothesis.If Ho is not rejected at a certain significant level, then it can be concluded that the model is accepted.In addition, the equation model can be evaluated descriptively with the GFI and AGFI goodnes of fit indices. The index value is equal to zero then the model is said not to be accepted, if the index value is more than or equal to 0.9 then the model concluded can be accepted.

\section{f. Model Specification}

This stage is carried out when testing the suitability produces a model that is less suitable. In this condition the researcher makes the decision how to delete, add or modify the path in the model and test it again.

\section{Reliability Test}

This reliability test aims to find out the valid data continuously or there are irregularities (some are not valid) so that it cannot be said that the data is reliable, this test must be available, to ensure that the data is suitable for use.

Reliability Test is used to determine the consistency of the measuring instrument used whether it is reliable and remains consistent if the measurement is repeated. Each question must be reliable and can be seen from the value of Cronbach's Alpha on each question.
According to Priyono (2008: 26), the data is considered reliable if the value of Cronbach Alpha> $r$ is critical of product moment.The method of testing is to calculate the magnitude of the Cronbach alpha coefficient for each instrument of the questionnaire to be tested with the aim of knowing the extent to which the measurement results remain consistent, if repeated measurements are made.

Reliability is the consistency of a measurement. High reliability indicates that indicators have a high consistency in measuring latent constructs. In general the techniques for estimating reliability are test-retest, alter.

Because in Cronbach's alpha the estimation will be too low if used to estimate congeneric measuredi in SEM, the measurement uses the composite reliability measure and the variance extracted measure. Native forms, split-halves and cronbach's alpha.

The composite reliability of a variable is calculated as follows:

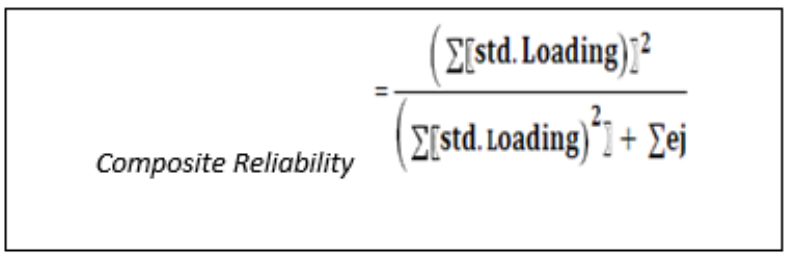

For std. loading (standard loading) can be obtained directly from the output of the LISREL- 8 program, and ej is the measurement error for each indicator (observed variable) (Fornel and Larker).

Variant extract reflects the total number of variants in the indicators (observed variables) that are explained by latent variable.

The size of the Variant Extract can be calculated with the following formula (Fornel and Laker, 1981):

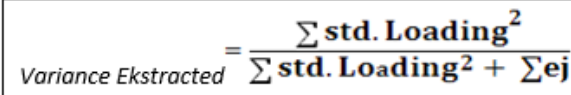

Or (Hair et.al 2007)

$$
\text { Variance Ekstracted }=\frac{\sum \text { std. Loading }}{\mathbf{N}}
$$

Information:

Std. Loading $=$ SLF Score (standardized loading factor)

$\mathrm{Ej}=$ Error variabel Score 
For $\mathrm{N}$ is the number of variables observed from the measurement model. Hair et.al (2007), states that a construct has good reliability if:

1) Construct Reliability (CR) value $\geq 0.7$ and

2) The Extracted Variance (VE) value $\geq 0.5$.

Testing of this research model was carried out using a structural equation model (SEM). Besides being known as the analysis of moment structures, this statistical analysis is used to estimate several separate but interconnected regressions simultaneously.

SEM data processing techniques with confirmatory analysis method are used in this study. The observed variable describes one specific latent variable. As a testing method that combines factor analysis, path analysis and SEM regression are more of a confirmatory method than an explanatory that aims to evaluate proposed proposed dimensions that originate from previous studies. With this understanding, SEM can be used as a tool to confirm preacquired knowledge.

The approach taken to estimate SEM model parameters is divided into 2, namely:

1) The structural model is also called the latent variable relationship.

2) The general equation is:

Endogenous latent variable $=$ function of exogenous latent variable + other endogenous latent variable + error

$$
n=\beta n+r \varepsilon+\zeta
$$

3) Confirmatory Factor Analysis (CFA) as a measurement model consists of 2 types of measurements, namely: Measurement model for exogenous variables (independent variable)

The general equation is:

Exogenous manifest variable $=$ function of the exogenous latent variable + error

$$
X=\wedge_{x} \varepsilon+\delta
$$

Measurement model for endogenous variables (dependent variable)

General equation:

Endogenous manifest variable $=$ function of the endogenous latent variable + error

The various equations above assume:

1) $\zeta$ cannot be correlated with $\varepsilon_{\text {o }}$

2) $\varepsilon$ cannot be correlated with $\eta$

3) $\delta$ cannot be correlated with $\varepsilon_{\text {, }}$

4) $\zeta, \varepsilon, \delta$ uncorrelated (mutually uncorrelated)

5) I, $\beta$ are non singular

These notations have the meaning as:

Variables:

$\eta$ ("eta") = latent endogenous variables

$\varepsilon_{0}($ "ksi") = latent exogenous variables

$\zeta$ ("zeta") = latent error in equation

$\mathrm{Y}=$ observed indicator of $\eta$

$\mathrm{Y}=$ observed indicator of $\varepsilon$,

$\varepsilon$ ("epsilon") $=$ measurement errors for $\mathrm{y}$

$\delta($ delta $)=$ measurement errors for $\mathrm{x}$

Coefficients :

$\beta$ (beta) is coefficient matrix for latent endogenous $\mathrm{I}$ (gamma) is coefficient matrix for latent exogenous $\wedge_{\mathrm{y}}$ (lamda y) is coefficeient matrix relating y to $\eta$ $\wedge_{\mathrm{y}}($ lamda $\mathrm{x})$ is coefficient matrix relating $\mathrm{x}$ toc,

The overall model fit for both the measurement model and the structural model is used to test the relationship model between dimensions / variables. 


\begin{tabular}{|c|c|c|}
\hline No & GDF Size & Criteria(Match Level) \\
\hline \multicolumn{3}{|c|}{ Ábsolute fitmeasure } \\
\hline 1 & Statistic Chi-Square (X2) & Follow statistical tests relating to significant requirements. The smaller the better \\
\hline 2 & Non-Centrality(NCP) & Expressed in the form of are-specification from Chi-Square. Assessment is based on comparison with other models. The smaller the better. \\
\hline 3 & ScaledNCP(SNCP) & The NCP is expressed in terms of the average difference of each observation in the tramework of comparison between models. The smaller the better. \\
\hline 4 & Goodness of fit Inden (GFl) & Values range from $0-1$, with higher values being better. GF $\mid 20.90$ is good fit, while $0.80<G F \mid<0.90$ is marginal fit \\
\hline 5 & Root Mean Square Residuan (RMR) & Average residuals between matrices (correlation or covariance) were observed and the estimation results. Standardized RMR 0.05 is a good fit \\
\hline \multirow[t]{2}{*}{6} & Root Mean Square Error of Approximation & Expected average per degree of freedom occurs in the population and not in the sample. RMSEA $\leq 0.08$ is good fit, while RMSEA $<0.05$ is close fit \\
\hline & (RMSEA) & \\
\hline 7 & ExpectedCross Validation(ECVII) & Used for comparison between models. The smaller the better. In a single model, the ECVI value of the model that approaches the saturated ECVI value indicates good fit \\
\hline \multicolumn{3}{|c|}{ Incremental fitmeasure } \\
\hline 1 & Tucker Lewis Inder or Non Normed Fit Index (TLINNNFI) & Values range from $0-1$, with higher values being better. TL12 0.90 is good fit, while $0.08 \mathrm{~s}$ TLIS 0.09 is marginal fit \\
\hline 2 & NormedFithdex(NFI) & Values range from 0 -1, with higher values being better. $N F \mid 20.90$ is good fit, while $0.08 \leq \mathrm{NF} \mid \leq 0.09$ is marginal fit \\
\hline 3 & Adjusted Goodness of Fitlndex (AGFl) & Values range from $0-1$, with higher values being better. AGF| 0.90 is good fit, while 0.08 s AGFIs 0.09 is marginal fit \\
\hline 4 & Relatiffitlnden(RFl) & Values range from $0-1$, with higher values being better. $\mathrm{RF} \mid 20.90$ is good fit, while $0.08 \mathrm{RF} \mid \leq 0.09$ is marginal fit \\
\hline 5 & IncrementalFit Index (IF|) & Values range from $0-1$, with higher values being better. $|F| z 0$, is good fit, while $0.08 \leq|F| \leq 0.09$ is marginal fit \\
\hline 6 & Comparative Fitlnden (CFl) & Values range from $0-1$, with higher values being better. $\mathrm{CF} \mid 20.90$ is good fit, while $0.08 \mathrm{~S} \mathrm{CF} \mid \leq 0.09$ is marginal fit \\
\hline \multicolumn{3}{|c|}{ Parsimonious titmeasure } \\
\hline 1 & Parsimoniuos Goodness of fit (PGFI) & The re-specifications of GFl, where higher values indicate greater parsimony. This measure is used for comparison between models. \\
\hline 2 & NormedChi-Square & The ratio between Chi Square divided by degree of freedom. The recommended lower limit: 1.0 , upper limit: 2.0 or 3.0 and the weaker 5.0 \\
\hline 3 & Parsimonious NormedFitlndex (PNFl) & High values indicate better compatibility, only used for comparisons between models \\
\hline \multirow[t]{2}{*}{4} & Akaike Information & Smaller positive values indicate better parsimony, used for comparisons between models. In a single model, the $A \mid C$ value of the model that approaches the Saturated $A \mid C$ value indicates good fit \\
\hline & Criterion $(\hat{A}[\mathbf{C})$ & \\
\hline 5 & Consistent Akaike Information Criterion (CAIC) & Smaller positive values indicate better parsimony, used for comparisons between models. In a single model, the CAIC value of the model that approaches the Saturated CAIC value indicates good fit \\
\hline \multicolumn{3}{|r|}{ 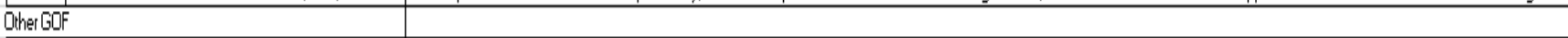 } \\
\hline 1 & Critical $4 N^{n}(\mathrm{CN})$ & $\mathrm{CN} z 200$ indicates a sufficient sample size to be used to estimate the model. Asatisfying or good match \\
\hline
\end{tabular}

Table 2. GOF Statistics Size

Following is an explanation of each criterion for all models in Table 2:

For the Absolute fit Measures group are as follows: 1) Chi-Square (X2) is the first and only statistical test in GOF.Chi-Square is used to test how close the match is between the covariance matrix of the $\mathrm{S}$ sample with the covariance matrix model $\sum(\Theta)$. The $\mathrm{X} 2$ statistical test is:

$$
X^{2}=(n-1) F(S, \Sigma(\theta))
$$

Df (degree of freedom) of c-p, in this case $c=(n x+$ ny) $(\mathrm{nx}+\mathrm{ny}+1) / 2$ is the number of non-redundant variance-covariance matrices of the observed variable. $\mathrm{Nx}$ is the number observed by variable $x$, ny is the number observed by variable $y$. The number of parameters is estimated and $u$ is the sample size.

2) Non-Centrality (NCP) is a measure of the difference between $\sum$ and $\sum(\Theta)$ which can be calculated using the formula:

$$
\mathrm{NCP}=X^{2}-\mathbf{d f}
$$

Where df is the degree of freedom.
3) Scaled NCP (SNCP) is the development of NCP by taking into account the sample size as below (Mc Donald and Marsh, 1990)

$$
\operatorname{SNCP}=\left(X^{2}-\mathrm{df}\right) / \mathrm{n}
$$

4) Goodness of fit Index (GFI) is a classification of absolute match size because basically GFI compares hypothesized models with no models at all $\left(\sum\left(\sum\right)\right)$. The formula of GFI is:here $\mathrm{n}$ is the sample size.

\section{GFI = $1-\dot{F} / F_{0}$}

Where :

$\dot{\mathrm{F}}$ : The minimum supply of $\mathrm{F}$ for the hypothesized model

Fo: The minimum value of $\mathrm{F}$, when no model is hypothesized

5) Root Mean Square Residue (RMR) represents the average residual value obtained from matching the variance-covariance matrix of the model hypothesized with the variance-covariance matrix from sample data.

6) Root Mean Square Error of Approximation (RMSEA) is one of the informative indices in SEM.

\section{RMSEA $=\mathbf{v} \dot{F}_{0} / d f$}


Where F́ $=\operatorname{Max}(\dot{\mathrm{F}}-\mathrm{df}(\mathrm{n}-1), 0)$

7) Expected Cross Validation (ECVI) is a means to assess, in a single sample, the likelihood that the model is crossvalidated with samples of the same size from the same population (Brown and Cudeck, 1989). ECVI is used for comparison of models and the smaller the value, the better the level of compatibility.

$$
E C V I=\dot{F}+2 q / n-1
$$
estimated.

$\mathrm{N}$ is the sample size and $\mathrm{q}$ is the number of parameters

1. The Incremental Fit Measures group is as Tucker Lewis Index or Non Normed Fit Index (TLI / NNFI) is a means to evaluate factor analysis which is then extended to SEM.follows:

$$
T L I=\left(X^{2} / d f\right)-\left(X_{h}^{2} / d f_{h}\right) /\left(X^{2} / d f\right)-1
$$

Note:

$\mathrm{X} 2$ = chi square of the null / independence model

$\mathrm{Xh} 2=$ chi square of the hypothesized model

$\mathrm{dfi}=$ degree of freedom from the null model

$\mathrm{dfh}=$ degree of freedom of the hypothesized model

2) Normed Fit Index (NFI) is a GOF measure proposed by Bentler and Bonnet (1980) in addition to NNFI.

$\mathrm{NFI}=\left(X_{i}^{2}-X_{i}^{2}\right) / X_{i}^{2}$

3) Adjusted Goodness of Fit Index (AGFI) is an extension of GFI adjusted to the ratio between the degree of freedom of the null / independence / baseline model and the degree of freedom of the hypothesized or estimated model.

Where :

dfo $=$ degree of freedom from no model $=p$

\section{1) $A G F I=1-d f_{o} / d f_{h}(1-G F I)$ \\ 2) $A G F I=1-p / d f_{h}(1-G F I)$}

$\mathrm{p}=$ number of variance and covariance of the observed variable

$\mathrm{dfh}=$ degree of freedom of the hypothesized model
4) Relative Fit Index (RFI) can be calculated using the formula:

$$
R F I=1-\left(\left(F_{h} / d f_{n}\right) /\left(F_{i} / d f_{i}\right)\right)
$$

Where :

$\mathrm{Fh}=$ The minimum value of $\mathrm{F}$ of the hypothesized model $\mathrm{Fi}=$ Minimum value $\mathrm{F}$ of the null / independence model.

5) The value of the Incremental Fit Index (IFI) can be obtained;

$$
I F I=\left(n F_{i}-n F_{h}\right) /\left(n F_{i}-d F_{h}\right)
$$

6) Comparative Fit Index (CFI) is an additional treasury of incremental matches through $\mathrm{CFI}$, the value of which can be calculated using the formula:

$$
\mathrm{CFI}=1-\left(I_{1} / I_{2}\right)
$$

Where :

$11=\max (\mathrm{lh}, 0)$ and $12=\max (\mathrm{lh}, \mathrm{li}, 0)$

$\mathrm{lh}=((\mathrm{n}-1) \mathrm{Fh}-\mathrm{dfh})$ and

$\mathrm{li}=((\mathrm{n}-1) \mathrm{Fi}-\mathrm{dfi})$

The Parsimonious Fit Measures group is as follows:

1) Parsimoniuos Goodness of fit (PGFI) is different from AGFI which modifies GFI based on degree of freedom, PGFI is based on parsimony of the estimated model.

\section{PGFI $=\left(d f_{h} / d f_{o}\right) \times G F I$}

2) Normed Chi-Square

$$
\text { Normed } X^{2}=X^{2} / d f_{h}
$$

3) Parsimonious Normed Fit Index (PNFI) is a modification of NFI. PNFI calculates the number of degrees of freedom to achieve a level of compatibility.

\section{PNFI $=\left(d f_{h} / d f_{i}\right) \times N F I$}

Where:

$\mathrm{dfh}=$ degree of freedom of the hypothesized model $\mathrm{dfi}=$ degree of freedom from independence / null model 4) Akaike Information Criterion (AIC) is a measure based on statistical information theory (Akaike, 1987). AIC is used to compare several models with a number of different constructs. 


\section{$\mathrm{AIC}=X^{2}+2 * q$}

Where :

$\mathrm{q}$ is the number of parameters estimated.

5) Consistent Akaike Information Criterion (CAIC) refines the previous AIC measure which only relates to the degree of freedom and CAIC adds by including the sample size.

\section{$\mathrm{CAIC}=X^{2}+(1+\ln n) * q$}

Where:

$\mathrm{n}$ is the number of observations

Another match size (Other GOFI) is $\mathrm{CN}$ (Critical N) which is the largest sample size that can be used to accept the hypothesis that the model is correct.

$$
\mathrm{CN}=\left(\left(X^{2} 1-\alpha\right) / F_{h}\right)+1
$$

Procedure SEM (Structural Equation Model)

According to Hair et al (2006) SEM procedure consists of 7 stages of SEM formation and analysis, namely:

1) Form a theoretical model as a basis for SEM capital that has a strong theoretical justification. Is a causal model / cause and effect that states the relationship between dimensions / variables.

2) Build a path diagram of a causal relationship formed by basic theory. The path diagram makes it easy for researchers to see the causality relationships that are tested.

3) Divide the path diagram into a set of measurement models (measurement models and structural models).

4) Select the input data matrix and estimate the proposed model. Difference between SEM and other multivariate techniques is in terms of input data used in modeling and estimation. SEM only uses variance / covariance matrix or correlation matrix as input data for overall estimations made.

5) Determine the identification of the structural model. This step is for the specified model not the unidentified / underidentified model.

6) Evaluate the criteria for goodness of fit.

7) Interpret the results obtained and change the model if necessary.

Limitation of SEM Analysis (Structural Equation Model)

Related to the title of this research, namely "The influence of motivation, competence and organizational climate on employee productivity" and the use of Structural Equation Model (SEM) as a data analysis technique, the analysis of the influence of variables in this study is limited to the partial effect of the independent variables on the dependent variable. This is related to the limitations of the analysis of the Structural Equation Model (SEM) itself..

\section{Dimension Analysis}

Dimension Analysis the purpose is to determine the relationship of the dimensions of the independent variable to the dimensions of the dependent variable.

For this reason a dimension correlation matrix is needed between the independent variables and the dependent variable.

\section{RESULTS AND DISCUSSION}

\section{A. Demographic Characteristics of Respondents.}

In the following, the writer will give a more comprehensive description of the respondents' description consisting of gender, age, last education, income, and occupation. Based on the answers to the questionnaires received it can be seen descriptive respondents, as in Table 3.

\begin{tabular}{|c|c|c|c|}
\hline No. & Description & $\begin{array}{c}\text { Frequency } \\
\text { (Person) }\end{array}$ & $\begin{array}{c}\text { Percentage } \\
(\%)\end{array}$ \\
\hline \multirow{3}{*}{1} & Gender of Respondents & & \\
\hline & - Male & 120 & 63.49 \\
\hline & - Female & 69 & 36.51 \\
\hline \multirow{5}{*}{2} & Age & & \\
\hline & - Less than 25 Years & 26 & 13.76 \\
\hline & - Between 26 - 35 Years & 84 & 44.44 \\
\hline & - Between 36 - 45 Years & 50 & 26.46 \\
\hline & - More Than 45 Years & 29 & 15.34 \\
\hline
\end{tabular}

Table 3. Demographic Characteristics of Respondents.

Based on Table 3. it can be seen that the characteristics of 189 respondents who are DKI Jakarta civil servants who have used or applied for the "Guna Bhakti" credit facility at BJB Rawamangun Branch are as follows:

A. Characteristics of respondents based on gender the composition of respondents is more male, namely 120 male $(63.49 \%)$ compared to 69 female $(36.51 \%)$.

B. Furthermore, from the age of respondents, 26 people $(13.76 \%)$ respondents were aged less than 25 years, 84 people $(44.44 \%)$ respondents were aged between 26-35 years, 50 people $(26.46 \%)$ respondents were aged between 36- 45 years, 29 people $(15.34 \%)$ of respondents were over 45 years old.

C. Descriptive Analysis of the Results of Questionnaire Answers

Based on the results of the responses of 189 respondents about the research variables, the researcher will 
describe in detail the answers of the respondents grouped in descriptive statistics. Submission of an empirical picture of the data used in descriptive statistical research is to use the average value, minimum value, maximum value, and data distribution. Through this description will be known to what extent the respondent of the variables that are indicators in the study. The following author will provide a more comprehensive picture of the description of the questionnaire answers received as follows:

\begin{tabular}{|c|c|c|c|c|c|c|c|c|}
\hline \multirow{2}{*}{ Indicator Code } & \multicolumn{5}{|c|}{ Respondents' Answers } & Total & Average & Average \\
\cline { 2 - 10 } & Strongly Disagree & Disagree & Neutrall & Agree & Strongly agree & & & \\
\hline P1 & 8 & 18 & 100 & 52 & 11 & 189 & 3.21 & 0.86 \\
\hline P2 & 8 & 26 & 89 & 54 & 12 & 189 & 3.19 & 0.9 \\
\hline P3 & 11 & 28 & 77 & 58 & 15 & 189 & 3.2 & 0.98 \\
\hline P4 & 6 & 44 & 60 & 66 & 13 & 189 & 3.19 & 0.98 \\
\hline P5 & 4 & 41 & 51 & 69 & 24 & 189 & 3.36 & 1.03 \\
\hline P6 & 3 & 45 & 49 & 76 & 16 & 189 & 3.3 & 0.98 \\
\hline P7 & 5 & 45 & 44 & 77 & 18 & 189 & 3.31 & 1.02 \\
\hline Total & 45 & 247 & 470 & 452 & 109 & 1323 & 3.25 & 0.83 \\
\hline Percentage & $3.40 \%$ & $18.67 \%$ & $35.53 \%$ & $34.16 \%$ & $8.24 \%$ & $100.00 \%$ & & \\
\hline
\end{tabular}

Table 4. Data Description Questionnaire Results Service Quality Variable $\left(\mathrm{X}_{1}\right)$

Based on table 4. above shows that for the questionnaire statement in the variable Service Quality (X1) there are 9 indicators, based on the distribution of data, as much as $2.47 \%$ of respondents stated strongly disagree, as much as $15.17 \%$ of respondents stated disagreeing, as much as $41.92 \%$ respondents stated neutral, as much as $33.39 \%$ of respondents agreed, and $7.05 \%$ of respondents stated strongly agree. The average result in this statement is 3.27 , which means that in the interpretation of intervals it falls into the "Agree" category, with the KUP7 indicator having the highest average of 3.35 which states that "Keeping customers' secrets well" is the most widely answered statement agree in the Service Quality variable.

\section{Table 5. Data Description Results Questionnaire QuestionsPromotion Variable (X2)}

Based on table 5. above shows that for the questionnaire statement in the Promotion variable (X2) there are 7 indicators, based on the distribution of data, as many as $3.4 \%$ of respondents stated strongly disagree, as much as

\begin{tabular}{|c|c|c|c|c|c|c|c|c|}
\hline \multirow{2}{*}{ Indicator Code } & \multicolumn{5}{|c|}{ Respondents' Answers } & \multirow{2}{*}{ Total } & \multirow{2}{*}{ Average } & \multirow{2}{*}{ Average } \\
\hline & Strongly Disagree & Disagree & Neutrall & Agree & Strongly agree & & & \\
\hline LP1 & 4 & 24 & 78 & 69 & 14 & 189 & 3.34 & 0.87 \\
\hline LP2 & 6 & 19 & 75 & 77 & 12 & 189 & 3.37 & 0.87 \\
\hline LP3 & 8 & 19 & 76 & 70 & 16 & 189 & 3.35 & 0.93 \\
\hline LP4 & 4 & 25 & 71 & 74 & 15 & 189 & 3.38 & 0.89 \\
\hline LP5 & 5 & 21 & 62 & 86 & 15 & 189 & 3.45 & 0.89 \\
\hline Total & 27 & 108 & 362 & 376 & 72 & 945 & 3.38 & 0.77 \\
\hline Percentage & $2.86 \%$ & $11.43 \%$ & $38.31 \%$ & $39.79 \%$ & $7.62 \%$ & $100,00 \%$ & & \\
\hline
\end{tabular}

\begin{tabular}{|c|c|c|c|c|c|c|c|c|}
\hline \multirow[b]{2}{*}{$\begin{array}{l}\text { Indicator } \\
\text { Code }\end{array}$} & \multicolumn{5}{|c|}{ Respondents' Answers } & \multirow[b]{2}{*}{ Total } & \multirow[b]{2}{*}{ Average } & \multirow[b]{2}{*}{ Std Deviation } \\
\hline & $\begin{array}{l}\text { Strongly } \\
\text { Disagree }\end{array}$ & Disagree & Neutrall & Agree & $\begin{array}{l}\text { Strongly } \\
\text { agree }\end{array}$ & & & \\
\hline KUP1 & 10 & 5 & 125 & 39 & 10 & 189 & 3.18 & 0.79 \\
\hline KUP2 & 5 & 13 & 113 & 37 & 21 & 189 & 3.30 & 0.85 \\
\hline KUP3 & 2 & 27 & 91 & 52 & 17 & 189 & 3.29 & 0.86 \\
\hline KUP4 & 3 & 32 & 77 & 64 & 13 & 189 & 3.28 & 0.88 \\
\hline KUP5 & 6 & 36 & 64 & 71 & 12 & 189 & 3.25 & 0.94 \\
\hline KUP6 & 5 & 34 & 63 & 75 & 12 & 189 & 3.29 & 0.93 \\
\hline KUP7 & 4 & 32 & 59 & 81 & 13 & 189 & 3.35 & 0.91 \\
\hline KUP8 & 3 & 39 & 57 & 79 & 11 & 189 & 3.30 & 0.92 \\
\hline KUP9 & 4 & 40 & 64 & 70 & 11 & 189 & 3.23 & 0.92 \\
\hline Total & 42 & 258 & 713 & 568 & 120 & 1701 & & \\
\hline Percentage & $2.47 \%$ & $15.17 \%$ & $41.92 \%$ & $\begin{array}{c}33.39 \\
\%\end{array}$ & $7.05 \%$ & $\begin{array}{c}100.0 \\
0 \%\end{array}$ & 3.27 & 0.75 \\
\hline
\end{tabular}

$18.67 \%$ of respondents stated disagree, as much as $35.53 \%$ respondents stated neutral, as much as $34.16 \%$ of respondents agreed and $8.24 \%$ of respondents expressed strongly agree. The average result in this statement is 3.25 , which means that in the interpretation of intervals it falls into the "Agree" category. These results indicate that the promotion within the scope of the sample is in the good category, with indicator P5 having the highest average of 3.36 which states that "BJB Marketing Bank is interesting in view and able to communicate well" is the most widely answered statement agreed in the variable Promotion.

\section{Table 6. Description of Data on Questionnaire Results}

Based on table 6. above shows that for the statement of the questionnaire in the Purchase Decision variable (Y), there are 6 indicators, based on the distribution of data, as many as $2.56 \%$ of respondents stated strongly disagree, as much as $13.84 \%$ of respondents stated disagree, as many as $44,09 \%$ of respondents stated neutral, $32.8 \%$ of respondents agreed and $6.7 \%$ of respondents strongly agreed. The average result in this statement is 3.27 , which means that in the interpretation of intervals it falls into the "Agree" category, with KP2 indicator having the highest average of 3.34 stating that "The brand image of the bjb bank attached to the PNS bank" is a statement the most widely answered agree in the Purchase Decision variable.

\begin{tabular}{|c|c|c|c|c|c|c|c|c|}
\hline \multirow{2}{*}{ Indicator Code } & \multicolumn{5}{|c|}{ Respondents' Answers } & \multirow{2}{*}{ Total } & \multirow{2}{*}{ Average } & \multirow{2}{*}{ Average } \\
\cline { 2 - 7 } & Strongly Disagree & Disagree & Neutrall & Agree & Strongly agree & & & \\
\hline KP1 & 6 & 14 & 100 & 54 & 15 & 189 & 3.31 & 0.84 \\
\hline KP2 & 4 & 19 & 90 & 60 & 16 & 189 & 3.34 & 0.85 \\
\hline KP3 & 5 & 24 & 83 & 63 & 14 & 189 & 3.3 & 0.88 \\
\hline KP4 & 5 & 32 & 76 & 67 & 9 & 189 & 3.23 & 0.88 \\
\hline KP5 & 2 & 32 & 80 & 64 & 11 & 189 & 3.26 & 0.85 \\
\hline KP6 & 7 & 36 & 71 & 64 & 11 & 189 & 3.19 & 0.94 \\
\hline Total & 29 & 157 & 500 & 372 & 76 & 1134 & 3.27 & 0.7 \\
\hline Percentage & $2.56 \%$ & $13.84 \%$ & $44.09 \%$ & $32.80 \%$ & $6.70 \%$ & $100.00 \%$ & & \\
\hline
\end{tabular}

Table 7. Data Description of Questionnaire Results Customer Loyalty Variable (Z)

Based on table 7 above shows that for the questionnaire statement in the variable Customer Loyalty (Z) there are 5 indicators, based on the distribution of data, as much as $2.86 \%$ of respondents stated strongly disagree, as much as $11.43 \%$ of respondents stated disagree, as much as $38.32 \%$ respondents stated neutral, as much as $39.79 \%$ of respondents agreed and $7.62 \%$ of respondents strongly agreed. The average result in this statement is 3.38 , which means that in the interpretation of intervals it falls into the 
"Agree" category. These results indicate that Customer Loyalty in the scope of the sample is already in the good category, with the LP5 indicator having the highest average of 3.45 stating that "Benefits felt in accordance with consumer expectations" is the statement most widely answered agree in the Loyalty variable Customer.

\section{Analysis Results}

To evaluate the model formed in this study, several tests were conducted to answer whether the latent variables studied, namely Service Quality, Promotion, Purchasing Decisions, and Customer Loyalty were consistently and accurately explained by each construct indicator. For this reason, 3 (three) testing phases are carried out, namely the overall model fit test, the measurement fit test and the structural equation fit test.

Hypothesis testing proposed in this study was carried out with a structural equation model (SEM) test, using the confirmatory factor analysis (CFA) measurement analysis method in the first stage using the LISREL 9.2 program

\section{A. Match Analysis of Measurement Models}

Testing the measurement model in SEM analysis is used to test the validity of the indicators in each construct. The construct validity test can be done by looking at the loading factor value of each indicator in the construct. In this test the indicator is declared valid if it has a loading factor value> 0.5 and $\mathrm{T}$-value> 1.96 , while the construct reliability test is performed by calculating the AVE and CR values of the construct, the construct is declared reliable if the AVE model $>0.5$ and the CR model $>0.7$ Following are the results of testing the measurement model for all constructs to be analyzed in SEM analysis.

\section{a) Test Validity and Reliability SEM}

The following are the results of testing the validity and reliability for each variable:

\section{a. CFA Variable Service Quality $\left(\mathbf{X}_{1}\right)$}

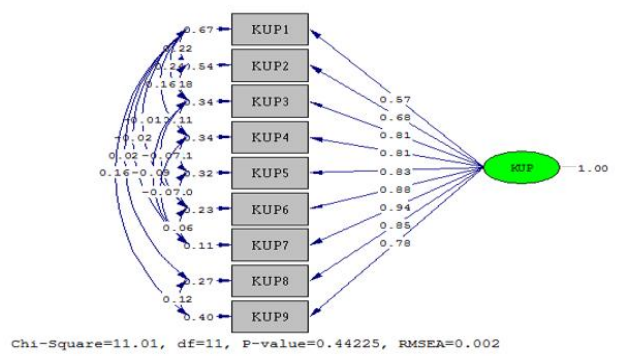

Figure 2.Variable Service Quality Variables $\left(\mathrm{X}_{1}\right)$ Based on Standard Solution

\begin{tabular}{|c|c|c|c|c|c|}
\hline \multirow{2}{*}{ Indicator Code } & \multirow{2}{*}{ SLF } & \multirow{2}{*}{ Standard Errors } & \multicolumn{2}{|c|}{ Reliability } & \multirow{2}{*}{ Information } \\
\cline { 4 - 5 } & & & CR $>0,70$ & VE $>0,5$ & \\
\hline KUP1 & 0.57 & 0.41 & 0.954 & 0.702 & Valid \\
\hline KUP2 & 0.68 & 0.4 & & & Valid \\
\hline KUP3 & 0.81 & 0.25 & & & Valid \\
\hline KUP4 & 0.81 & 0.26 & & & Valid \\
\hline KUP5 & 0.83 & 0.28 & & & Valid \\
\hline KUP6 & 0.88 & 0.19 & & & Valid \\
\hline KUP7 & 0.94 & 0.09 & & & Valid \\
\hline KUP8 & 0.85 & 0.23 & & & Valid \\
\hline KUP9 & 0.78 & 0.34 & & & Valid \\
\hline
\end{tabular}

Table 8. Test Results of Validity and Reliability of Service Quality Variables $\left(\mathrm{X}_{1}\right)$

Table 8. and Figure 2. above show that there are 9 indicator variables observed in the latent variable Service Quality (X1) that have passed the validity test, because of the 9 variable indicators all loading factors $>0.50$. While the reliability test results of Service Quality (X1) results in good reliability values where the results of the Construct Reliability $(\mathrm{CR})$ value $=0.954>0.7$, and the Variance Extracted (VE) value of 0.702> 0.50. Thus the latent variable Service Quality (X1) has met the validity and reliability test requirements.

\begin{tabular}{|l|c|c|c|c|}
\hline \multirow{2}{*}{\multicolumn{2}{|c|}{ Goodness of Fit Size }} & \multicolumn{2}{|c|}{ Match Size } & \multicolumn{2}{c|}{ Measurement results } \\
\cline { 2 - 3 } & Good Fit & Marginal Fit & \multicolumn{2}{c|}{} \\
\hline Normed Chi-Square (X2/df) & $<2.0$ & & 1.001 & Fit \\
\hline Root Mean Square Error (RMSEA) & $<0.08$ & & 0.0024 & Fit \\
\hline Root Mean Square Residual (RMR) & $<0.05$ & & 0.014 & Fit \\
\hline Goodness of Fit Index (GFI) & $\geq 0.90$ & $0.70<0.90$ & 0.99 & Fit \\
\hline Normal Fit Index (NFI) & $\geq 0.90$ & $0.80-<0.90$ & 1 & Fit \\
\hline Non-Normed Fit Index (NNFI) & $\geq 0.90$ & $0.80-<0.90$ & 1 & Fit \\
\hline Comparative Fit Index (CFI) & $\geq 0.90$ & $0.80-<0.90$ & 1 & Fit \\
\hline Increamental Fit Index (IFI) & $\geq 0.90$ & $0.80-<0.90$ & 1 & Fit \\
\hline Relative Fit Index (RFI) & $\geq 0.90$ & $0.80-<0.90$ & 0.99 & Fit \\
\hline
\end{tabular}

Table 9. Goodness of Fit CFA Model of Service Quality Variable $\left(\mathrm{X}_{1}\right)$

Based on the results of the model compatibility test in Table 9 above, it shows that the CFA model of the construct of Service Quality has met the requirements of construct validity with the category of the model being fit.

\section{b. Promotion Variable CFA $\left(\mathbf{X}_{2}\right)$}

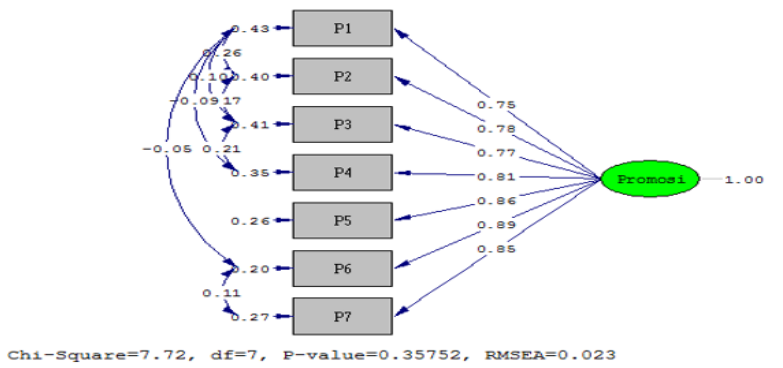

Figure 3. Construction of Promotional Variables $\left(\mathrm{X}_{2}\right)$ Based on Standard Solution 


\begin{tabular}{|c|c|c|c|c|c|}
\hline \multirow{2}{*}{ Indicator Code } & \multirow{2}{*}{ SLF } & \multirow{2}{*}{ Standard Errors } & \multicolumn{2}{|c|}{ Reliability } & \multirow{2}{*}{ Information } \\
\cline { 4 - 5 } & & & CR $>0,70$ & VE $>0,5$ & \\
\hline P1 & 0.75 & 0.32 & 0.94 & 0.69 & Valid \\
\hline P2 & 0.78 & 0.32 & & & Valid \\
\hline P3 & 0.77 & 0.39 & & & Valid \\
\hline P4 & 0.81 & 0.33 & & & Valid \\
\hline P5 & 0.86 & 0.27 & & & Valid \\
\hline P6 & 0.89 & 0.19 & & & Valid \\
\hline P7 & 0.85 & 0.28 & & & Valid \\
\hline
\end{tabular}

Table 10. Results of Validity and Reliability Test Promotional Variables $\left(\mathrm{X}_{2}\right)$

Table 10. andFigure 3. above shows that there are 7 indicator variables observed in the Promotional latent variable $\left(\mathrm{X}_{2}\right)$ that have passed the validity test, because of the 7 variable indicators all loading factors $>0.50$. While the reliability variable test results Promotions $\left(\mathrm{X}_{2}\right)$ produce good reliability values where the results of the Construct Reliability $(\mathrm{CR})=0.94>0.7$ and the Variance Extracted (VE) value of $0.69>0.50$. Thus the Promotional latent variable $\left(\mathrm{X}_{2}\right)$ meets the validity and reliability test requirements.

\begin{tabular}{|c|c|c|c|c|}
\hline \multirow{2}{*}{ Goodness of Fit Size } & \multicolumn{2}{|c|}{ Match Size } & \multirow{2}{*}{ Measurement results } \\
\cline { 2 - 3 } & Good Fit & Marginal Fit & \multicolumn{2}{|c|}{} \\
\hline Normed Chi-Square (X2/df) & $<2.0$ & & 1.103 & Fit \\
\hline Root Mean Square Error (RMSEA) & $<0.08$ & & 0.023 & Fit \\
\hline Root Mean Square Residual (RMR) & $<0.05$ & & 0.015 & Fit \\
\hline Goodness of Fit Index (GFI) & $\geq 0.90$ & $0.70<0.90$ & 0.99 & Fit \\
\hline Normal Fit Index (NFI) & $\geq 0.90$ & $0.80-<0.90$ & 1 & Fit \\
\hline Non-Normed Fit Index (NNFI) & $\geq 0.90$ & $0.80-<0.90$ & 1 & Fit \\
\hline Comparative Fit Index (CFI) & $\geq 0.90$ & $0.80-<0.90$ & 1 & Fit \\
\hline Increamental Fit Index (IFI) & $\geq 0.90$ & $0.80-<0.90$ & 1 & Fit \\
\hline Relative Fit Index (RFI) & $\geq 0.90$ & $0.80-<0.90$ & 0.99 & Fit \\
\hline
\end{tabular}

Table 11. Goodness of Fit Model CFA Constructions of Promotion Variables $\left(\mathrm{X}_{2}\right)$

Based on the results of the model match test in table 11. above shows that the CFA model of the Promotion construct has fulfilled the construct validity requirements with the model category already fit.

\section{c. CFA Purchase Decision Variable (Y)}

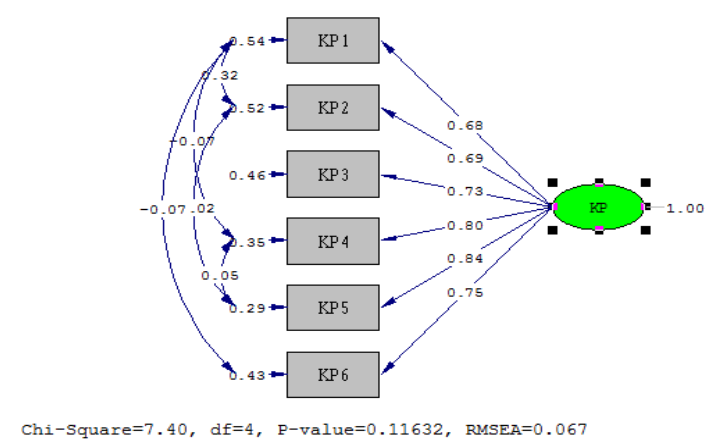

Figure 4. Variable Constructions of Purchase Decisions (Y) Based on Standard Solution

\begin{tabular}{|c|c|c|c|c|c|}
\hline \multirow{2}{*}{ Indicator Code } & \multirow{2}{*}{ SLF } & \multirow{2}{*}{ Standard Errors } & \multicolumn{2}{|c|}{ Reliability } & \multirow{2}{*}{ Information } \\
\cline { 4 - 5 } & & & CR $>\mathbf{0 , 7 0}$ & VE $>\mathbf{0 , 5}$ & \\
\hline KP1 & 0.68 & 0.38 & 0.91 & 0.63 & Valid \\
\hline KP2 & 0.69 & 0.38 & & & Valid \\
\hline KP3 & 0.73 & 0.36 & & & Valid \\
\hline KP4 & 0.8 & 0.27 & & & Valid \\
\hline KP5 & 0.84 & 0.21 & & & Valid \\
\hline KP6 & 0.75 & 0.38 & & & Valid \\
\hline
\end{tabular}

Table 12. Test Results of Validity and Reliability of Purchasing Decision Variables (Y)

Table 12. and Figure 4 above shows that there are 6 indicator variables observed in the purchasing decision latent variable $(\mathrm{Y})$ that have passed the validity test, because of the 6 indicator variables all loading factors $>0.50$. While the results of the reliability test variable Purchase Decision (Y) produces a good reliability value where the results of the value of Construct Reliability $(\mathrm{CR})=0.91>0.7$ and the Variance Extracted (VE) value of $0.63>0.50$. Thus the latent variable Purchase Decision (Y) meets the validity and reliability test requirements.

\begin{tabular}{|l|c|c|c|c|}
\hline \multirow{2}{*}{\multicolumn{1}{|c|}{ Goodness of Fit Size }} & \multicolumn{2}{|c|}{ Match Size } & \multicolumn{2}{c|}{ Measurement results } \\
\cline { 2 - 3 } & Good Fit & Marginal Fit & \multicolumn{2}{c|}{} \\
\hline Normed Chi-Square $(\mathrm{X} 2 / \mathrm{df})$ & $<2.0$ & & 1.85 & Fit \\
\hline Root Mean Square Error (RMSEA) & $<0.08$ & & 0.06 & Fit \\
\hline Root Mean Square Residual (RMR) & $<0.05$ & & 0.019 & Fit \\
\hline Goodness of Fit Index (GFI) & $\geq 0.90$ & $0.70<0.90$ & 0.99 & Fit \\
\hline Normal Fit Index (NFI) & $\geq 0.90$ & $0.80-<0.90$ & 0.99 & Fit \\
\hline Non-Normed Fit Index (NNFI) & $\geq 0.90$ & $0.80-<0.90$ & 0.99 & Fit \\
\hline Comparative Fit Index (CFI) & $\geq 0.90$ & $0.80-<0.90$ & 1 & Fit \\
\hline Increamental Fit Index (IFI) & $\geq 0.90$ & $0.80-<0.90$ & 1 & Fit \\
\hline Relative Fit Index (RFI) & $\geq 0.90$ & $0.80-<0.90$ & 0.97 & Fit \\
\hline
\end{tabular}

Table 13. Goodness of Fit CFA Model Variable Constructions for Purchasing Decisions (Y)

Based on the results of the model match test in table 13. above shows that the CFA model of the Purchase Decision construct fulfills the construct validity requirements with the model category already fit.

\section{d. CFA Variable Customer Loyalty (Z)}

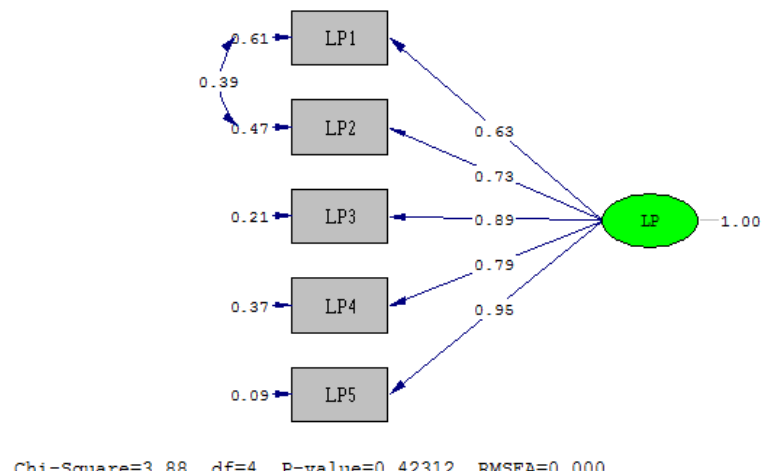

Figure 5. Variable Customer Loyalty (Z) Constructions Based on Standard Solution 


\begin{tabular}{|c|c|c|c|c|c|}
\hline \multirow{2}{*}{ Indicator Code } & \multirow{2}{*}{ SLF } & \multirow{2}{*}{ Standard Errors } & \multicolumn{2}{|c|}{ Reliability } & \multirow{2}{*}{ Information } \\
\cline { 3 - 5 } & & & CR $>0,70$ & VE $>0,5$ & \\
\hline LP1 & 0.63 & 0.46 & 0.92 & 0.71 & Valid \\
\hline LP2 & 0.73 & 0.35 & & & Valid \\
\hline LP3 & 0.89 & 0.18 & & & Valid \\
\hline LP4 & 0.79 & 0.29 & & & Valid \\
\hline LP5 & 0.95 & 0.07 & & & Valid \\
\hline
\end{tabular}

Table 14. Test Results of Validity and Reliability of Customer Loyalty Variables (Z)

Table 14. and Figure 5 above show that there are 5 indicator variables observed in the latent variable Customer Loyalty $(Z)$ that has passed the validity test, because of the 5 indicator variables all loading factors> 0.50. While the results of the reliability test variable Customer Loyalty $(\mathrm{Z})$ produces a good reliability value where the value of the Construct Reliability $(\mathrm{CR})=0.92>0.7$, and the Variance Extracted (VE) value of $0.71>0.50$. Thus the latent variable Customer Loyalty (Z) has fulfilled the validity and reliability test requirements.

\begin{tabular}{lcccc}
\hline \multirow{2}{*}{ Goodness of Fit Size } & \multicolumn{2}{c}{ Match Size } & \multirow{2}{*}{ Measurement Results } \\
\cline { 2 - 3 } & Good Fit & Marginal Fit & & \\
\hline Normed Chi-Square $\left(X^{2} /\right.$ df) & $<2.0$ & & 0.97 & Fit \\
\hline Root Mean Square Error (RMSEA) & $<0.08$ & & 0.0001 & Fit \\
\hline Root Mean Square Residual (RMR) & $<0.05$ & & 0.012 & Fit \\
\hline Goodness of Fit Index (GFI) & $\geq 0.90$ & $0.70<0.90$ & 0.99 & Fit \\
\hline Normal Fit Index (NFI) & $\geq 0.90$ & $0.80-<0.90$ & 1 & Fit \\
\hline Non-Normed Fit Index (NNFI) & $\geq 0.90$ & $0.80-<0.90$ & 1 & Fit \\
\hline Comparative Fit Index (CFI) & $\geq 0.90$ & $0.80-<0.90$ & 1 & Fit \\
\hline Increamental Fit Index (IFI) & $\geq 0.90$ & $0.80-<0.90$ & 1 & Fit \\
\hline Relative Fit Index (RFI) & $\geq 0.90$ & $0.80-<0.90$ & 0.99 & Fit \\
\hline
\end{tabular}

Table 15. Goodness of Fit CFA Model Variable Customer Loyalty (Z)

Based on the results of the model match test in table 15 above shows that the CFA model construct Customer Loyalty has met the requirements of the construct validity with the model category already fit.

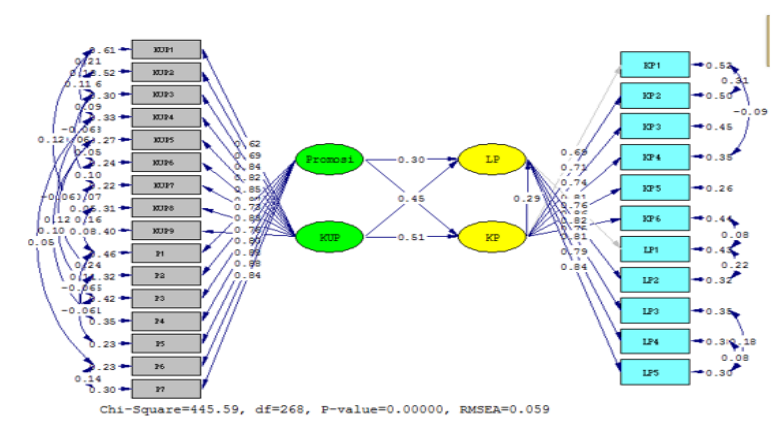

b) Structural Model Suit Analysis

After calculating and analyzing the Confirmatory Factor Analysis (CFA), the following is a structural equation model measurement variable to analyze the relationship between compatibility and hypothesis on the research variables. Overall model compatibility test is performed to see how well the resulting model describes the actual conditions. Data processing is done by using the maximum likelihood method in the Lisrel 9.2 application. Based on data processing, the goodness of fit of the structural equation is described in Figure 6.

\section{Figure 6. Overall Variable Model}

\section{c) Structural Model Match Test}

After testing the suitability of the whole model, the next step is to test the research hypothesis in the structural model.Model testing is done to find out how the relationship between the variable Service Quality (X1), Promotion (X2), Purchase Decision (Y), and Customer Loyalty (Z). With this test it will be known whether the research model hypothesis is accepted or rejected. All variables in this study were measured using 27 observable indicators / variables in the form of statements, namely each latent variable consists of: Service Quality, 9 indicators, Promotion with 7 indicators, Purchase Decision with 6 indicators, and Loyalty. The customer consists of 5 indicators. Hypothesis test results can be seen from the printed output of the syntax process in the researchers' processed equation equation and also found in the path diagram. Significant relationships will be marked with a black $t$-value on the path diagram with a value $\geq$ 1.96. While the insignificant relationship is indicated by the red $t$-value in the path diagram with a value below 1.96 . The path diagram shown in Figure 6.provides an overview of the relationship between latent variables Service Quality (X1), Promotion (X2), Purchase Decision (Y), and Customer Loyalty (Z).In the validity and reliability test before testing the model, all variables in the study have been tested for validity and reliability because they meet the requirements with a value of $\geq 1$.96.After obtaining the structural model specifications, the next step is to analyze the Goodness of Fit $(\mathrm{GoF})$ statistics on the overall model.This test evaluates whether the resulting model is a fit model or not. Following are the Goodness of Fit test results from the whole model:

\begin{tabular}{lccccc}
\hline \multirow{2}{*}{ Goodness of Fit Size } & \multicolumn{2}{c}{ Match Size } & \multirow{2}{*}{ Measurement Results } \\
\cline { 2 - 3 } & Good Fit & Marginal Fit & & 1.663 & Fit \\
\hline Normed Chi-Square $\left(\chi^{2} /\right.$ df $)$ & $<2.0$ & & 0.059 & Fit \\
\hline $\begin{array}{l}\text { Root Mean Square Error } \\
\text { (RMSEA) }\end{array}$ & $<0.08$ & & 0.036 & Fit \\
\hline $\begin{array}{l}\text { Root Mean Square Residual } \\
\text { (RMR) }\end{array}$ & $<0.05$ & & 0.85 & $\begin{array}{c}\text { Marginal } \\
\text { Fit }\end{array}$ \\
\hline Goodness of Fit Index (GFI) & $\geq 0.90$ & $\begin{array}{c}0.70< \\
0.90\end{array}$ & $\begin{array}{c}0.80-< \\
0.90\end{array}$ & 0.98 & Fit \\
\hline Normal Fit Index (NFI) & $\geq 0.90$ & $\begin{array}{c}0.80-< \\
0.90\end{array}$ & 0.99 & Fit \\
\hline Non-Normed Fit Index (NNFI) & $\geq 0.90$ & $\begin{array}{c}0.80-< \\
0.90\end{array}$ & 0.99 & Fit \\
\hline Comparative Fit Index (CFI) & $\geq 0.90$ & $\begin{array}{c}0.80-< \\
0.90\end{array}$ & 0.99 & Fit \\
\hline Increamental Fit Index (IFI) & $\geq 0.90$ & $\begin{array}{c}0.80-< \\
0.90\end{array}$ & 0.97 & Fit \\
\hline Relative Fit Index (RFI) & $\geq 0.90$ & & &
\end{tabular}

Table 16. Goodness of Fit Full Model

SEM analysis results illustrate the value of GFI 0.85 close to 0.90 (marginal fit), the value of RMSEA 0.059 $<0.08$ (model fit), this shows that the structural equation 
model meets the absolute fit measure requirements which means that the structural equation model in this study as a whole has conformity with the data.In the incremental fit measure requirements NNFI / TLI value $0.99 \geq 0.90$ (model fit), CFI value $0.99 \geq 0.90$ (model fit), RFI value $0.97 \geq 0.90$ (model fit), NFI value $0.98 \geq 0.90$ (model fit), and IFI 0.99 $\geq 0.90$ (model fit), shows that the structural equation model meets the incremental fit measure requirements. Then for the parsimonious fit measure requirement, the normed chisquare value of $1,663<2.0$ (model fit), indicates that the structural equation model meets the parsimonious fit measure requirements, which means overall the structural equation model in this study has comparative compatibility with the baseline model (null model).

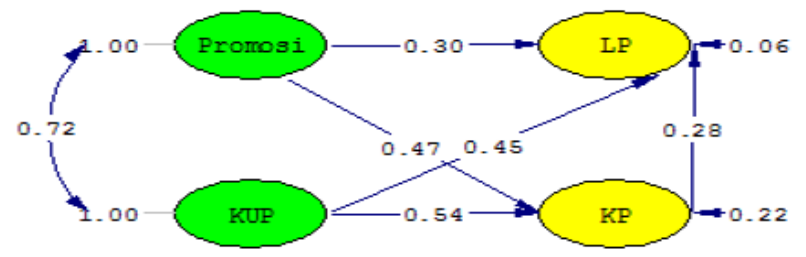

Figure 7. Structural Model Estimates Using Lisrel 9.2

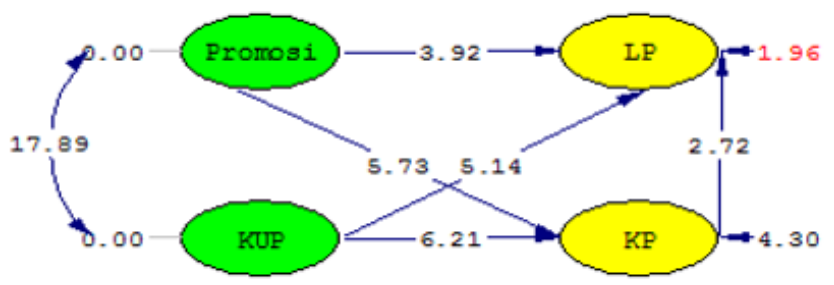

Figure 8. Structural Model t-Value Using Lisrel 9.2

Based on the SEM analysis results of the structural equation model in Figure 8, the causal relationship between the independent and dependent latent variables is as follows:

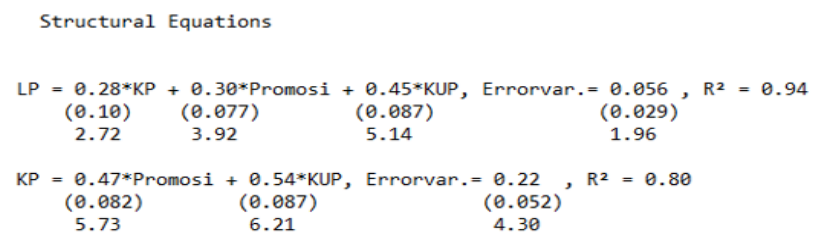

Figure 9. Output Structural Equation Model

The coefficient of determination (R2) is used to measure how well the regression line matches the actual (Goodness of Fit). This coefficient of determination measures the percentage of the total variation of the dependent variable, from the calculations performed obtained the coefficient of determination from Figure 9. can be seen that: for the dependent variable Purchase Decision of 0.80 means $80 \%$ of the variations that can be explained by the independent variable Service Quality, and Promotion while the remaining 0.20 or $20 \%$ is explained by other variables outside the variables used in the study.Service Quality, and Promotion have a significant positive relationship to Purchasing Decisions (Y) with coefficient values of 0.54 , and 0.47 which are positive.

While the dependent variable Customer Loyalty of 0.94 means that $94 \%$ of the variations that can be explained by the independent variable Service Quality, Promotion, and Purchasing Decisions, the remaining 0.6 or $6 \%$ is explained by other variables outside the variables used in research. Service Quality, Promotion, and Purchasing Decisions have a significant positive relationship on Customer Loyalty. This is indicated by the coefficient values of $0.45,0.30$ and 0.28 which are positive.

\section{Hypothesis Testing}

Based on the results of the structural model compatibility test conducted previously, seven research hypotheses have been proven to have a significant relationship at the $95 \%$ confidence level with t value> 1.96 . In general, the conclusions from the results of hypothesis testing, indirect effects, and estimation of the regression coefficients can be seen in the following table:

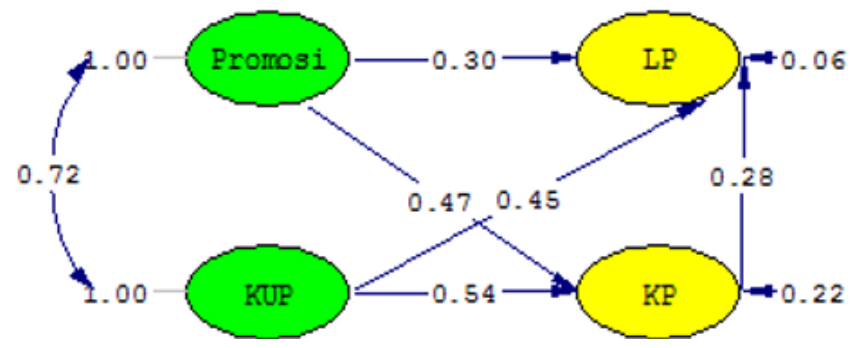

Figure 10. Estimates Structural Model Pathways

\begin{tabular}{|l|c|c|c|}
\hline \multicolumn{1}{|c|}{ Relationship Between Constructions } & Estimates & T-Values & Information \\
\hline Service Quality $>$ Buying Decision & 0.54 & 6.21 & Significantly Positive Influence \\
\hline Promotion $>$ Buying Decision & 0.47 & 5.73 & Significantly Positive Influence \\
\hline Service Quality -> Customer Loyalty & 0.45 & 5.14 & Significantly Positive Influence \\
\hline Promotion $>$ Customer Loyalty & 0.3 & 3.92 & Significantly Positive Influence \\
\hline Buying Decision $>$ Customer Loyalty & 0.28 & 2.72 & Significantly Positive Influence \\
\hline
\end{tabular}

Table 17. Hypothesis Testing

Hypothesis testing in this study based on Figure 10. and Table 17. are as follows:

1. There is a Significant Effect of Service Quality $\left(\mathrm{X}_{1}\right)$ on Purchasing Decisions (Y)

Based on table 17.note the value of $t-V$ alues $=6.21>$ 1.96. The coefficient value is positive that is equal to 0.54 means that the variable Service Quality $\left(\mathrm{X}_{1}\right)$ has a positive effect on the Purchase Decision variable (Y) of 54\%.Thus the $\mathrm{H}_{1}$ hypothesis in this study which states that "Service Quality $\left(\mathrm{X}_{1}\right)$ has a significant effect on Purchasing Decisions (Y) is accepted.

2. There is a Significant Effect of Promotion $\left(\mathrm{X}_{2}\right)$ on Purchasing Decisions (Y) 
Based on table 17. it is known that the value of tValues $=5.75$ which is greater than $\mathrm{t}=1.96$ The coefficient value is positive that is equal to 0.47 means that the Promotion variable (X2) has a positive effect on the Purchase Decision variable (Y) of $47.0 \%$. Thus the $\mathrm{H} 2$ hypothesis in this study which states that "Promotion (X2) has a significant effect on Purchasing Decisions (Y)" is accepted.

3. There is a Significant Effect of Service Quality $\left(X_{1}\right)$ on Customer Loyalty $(\mathrm{Z})$

Based on table 17. known value of t-Values $=5.14>$ 1.96. The coefficient value is positive that is equal to 0.45 meaning that the Service Quality variable (X1) has a positive effect on the Customer Loyalty (Z) variable of $45 \%$. Thus the H3 hypothesis in this study which states that "Service Quality (X1) has a significant effect on Customer Loyalty (Z) is accepted.

\section{There is a Significant Effect of Promotion $\left(X_{2}\right)$ on Customer Loyalty (Z)}

Based on table 17. it is known that the value of tValues $=3.92$ is greater than $t=1.96$ The coefficient value is positive that is equal to 0.30 meaning that the Promotion variable (X2) has a positive effect on the Customer Loyalty (Z) variable of $30.0 \%$. Thus the hypothesis $\mathrm{H} 4$ in this study which states that "Promotion (X2) has a significant effect on Customer Loyalty (Z)" is accepted.

5. There is a Significant Effect of Purchasing Decisions (Y) on Customer Loyalty (Z).

Based on table 17. it is known that the value of tValues $=2.72$ is greater than $t=1.96$ The coefficient value is positive that is equal to 0.28 meaning that the Purchase Decision variable (Y) has a positive effect on the Customer Loyalty (Z) variable of $28,0 \%$. Thus the hypothesis H5 in this study which states that the "Purchasing Decision (Y) has a significant effect on Customer Loyalty (Z)" is accepted.

\section{E. Analysis of Indirect Effects}

To see the indirect effect of Service Quality and Promotion variables on Customer Loyalty can be seen in Figure 11. Estimate structural path diagram below:

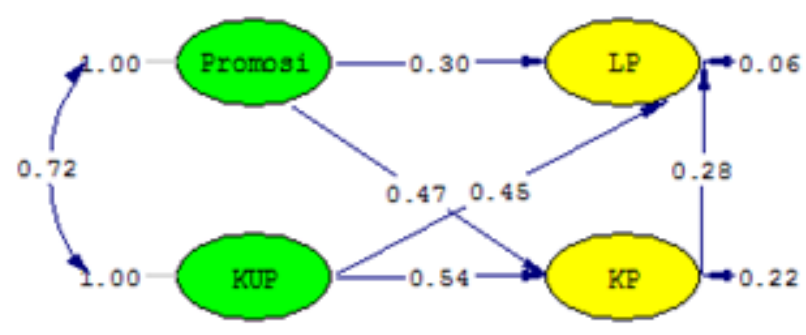

Figure 11. Estimate Structure Model Path Diagram
Indirect Effects of KSI on ETA

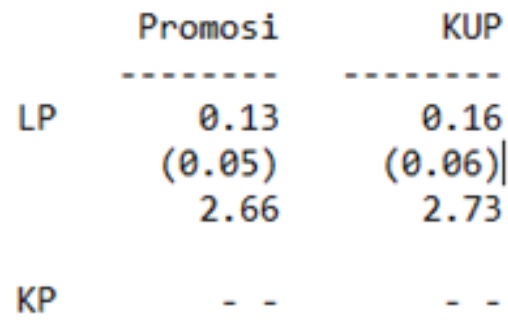

Figure 12. Output of Indirect Effects

\begin{tabular}{|c|c|c|c|c|}
\hline & Reltionstip Between Constutions & Etimates & TValues & Informtion \\
\hline \multirow{2}{*}{ Indiredt } & 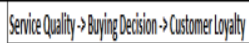 & 0.16 & $2 B 3$ & Sigifinatrappositiven \\
\hline & 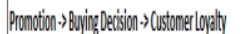 & 0.13 & 266 & Sigififantity positive hativ \\
\hline
\end{tabular}

Table 18. Direct and Indirect Effects

Based on Figure 11. 12. and table 18. can be interpreted as follows:

I. There is a Significant Effect of Service Quality $\left(\mathrm{X}_{1}\right)$ on Customer Loyalty $(\mathrm{Z})$ through the Purchase Decision variable (Y)

Based on table 18. known t-value values $=2.73>1.96$. The coefficient value is positive that is equal to $0.16(0.54 \mathrm{x}$ $0.28)$ meaning that the Service Quality variable $\left(X_{1}\right)$ has a positive effect on the Customer Loyalty $(\mathrm{Z})$ variable through the Purchase Decision variable (Y) of $16 \%$. Thus the indirect influence hypothesis in this study which states that "Service Quality (X1) has a significant effect on Customer Loyalty (Z) through Purchasing Decisions" is accepted.

II. There is a significant Promotion Effect $\left(\mathrm{X}_{2}\right)$ on Customer Loyalty $(\mathrm{Z})$ through the Purchase Decision variable (Y)

Based on table 18. known value of t-Values $=2.66$ which is greater than $\mathrm{t}=1.96$ The coefficient value is positive that is equal to $0.13(0.47 \times 0.28)$ means that the promotion variable $\left(\mathrm{X}_{2}\right)$ has a positive effect on the variable Customer Loyalty $(\mathrm{Z})$ through the Purchase Decision variable (Y) of $13.0 \%$. Thus the indirect influence hypothesis in this study which states that "Promotion $\left(\mathrm{X}_{2}\right)$ has a significant effect on Customer Loyalty (Z) through Purchasing Decisions" is accepted.

F. Discussion of Hypothesis Tests

a) Effect of Service Quality on Purchasing Decisions (Y) Directly

Research hypothesis $\left(\mathrm{H}_{1}\right)$ states that Service Quality has a positive and significant effect directly on Purchasing Decisions.Test results with SEM show that Service Quality has a positive and significant influence on Purchasing 
Decisions, this can be seen from the t-value 6.21 greater than 1.96, and the estimated value of 0.54 or $54.0 \%$ influence on Purchasing Decisions.In other words, if the Service Quality has improved it will affect the Purchasing Decision.

The results of this study also confirm research results from Homson P. S and LiastaGinting (2015). Based on these empirical facts and supported by the results of previous studies it can be concluded that the research hypothesis $\left(\mathrm{H}_{1}\right)$ can be accepted that Service Quality has a positive and significant effect directly on Purchasing Decisions.

\section{b) Effect of Promotion on Purchasing Decisions (Y) Directly}

The research hypothesis (H2) states that Promotion has a positive and significant direct effect on Purchasing Decisions. The results of testing with SEM show that promotion affects positively and significantly on Purchasing Decisions, this can be seen from the t-value 5.73 greater than 1.96, and the estimated value of 0.47 or $47.0 \%$ its effect on the Purchasing Decision.In other words, if the Promotion has increased it will affect the Purchasing Decision.

The results of this study also confirm the results of research from Muhammad FajarFahrudin (2015). Based on these empirical facts and supported by the results of previous studies it can be concluded that the research hypothesis $\left(\mathrm{H}_{2}\right)$ can be accepted that the promotion has a positive and significant effect directly on the Purchasing Decision.

\section{c) Effect of Service Quality on Customer Loyalty (Z) Directly}

The research hypothesis $\left(\mathrm{H}_{3}\right)$ states that Service Quality has a positive and significant effect directly on Customer Loyalty.Test results with SEM show that Service Quality has a positive and significant effect on Customer Loyalty, this can be seen from the t-value 5.14 greater than 1.96 , and the estimated value of 0.45 or $45.0 \%$ effect on Customer Loyalty. In other words, if the Quality of Service has improved it will affect Customer Loyalty.

The results of this study also confirm the results of research from AinulYaqin (2016). Based on these empirical facts and supported by the results of previous studies it can be concluded that the research hypothesis (H3) can be accepted that Service Quality has a positive and significant effect directly on Customer Loyalty.

\section{d) Effect of Promotion on Customer Loyalty (Z) Directly}

The research hypothesis $\left(\mathrm{H}_{4}\right)$ states that Promotion has a positive and significant effect directly on Customer Loyalty. The results of testing with SEM show that promotion affects positively and significantly on customer loyalty, this can be seen from the t-value 3.92 is greater than
1.96, and the estimated value of 0.30 or $30.0 \%$ influence on customer loyalty. In other words, if the Promotion has increased it will affect Customer Loyalty.

The results of this study also confirm the results of research from Aditya Rizky (2019). Based on these empirical facts and supported by the results of previous studies it can be concluded that the research hypothesis $\left(\mathrm{H}_{4}\right)$ can be accepted that Promotion has a positive and significant effect directly on Customer Loyalty.

\section{Effect of Purchasing Decisions (Y) on Customer Loyalty} (Z)

The research hypothesis $\left(\mathrm{H}_{5}\right)$ states that Purchasing Decisions have a positive and significant effect directly on Customer Loyalty. Test results with SEM show that the Purchase Decision affects positively and significantly on Customer Loyalty, this can be seen from the t-value 2.72 greater than 1.96 , and the estimated value of 0.28 or $28.0 \%$ influence on Customer Loyalty. These results indicate that the Purchase Decision has a significant effect on Customer Loyalty. In other words, if the Purchase Decision has increased it will affect Customer Loyalty

The results of this study also confirm the results of research from SerlyAyu Novita Devi (2019). Based on these empirical facts and supported by the results of previous studies it can be concluded that the research hypothesis $\left(\mathrm{H}_{5}\right)$ can be accepted that the Purchasing Decision has a positive and significant effect directly on Customer Loyalty.

\section{CONCLUSIONS}

After testing the research hypothesis with Structural Equation Modeling data analysis techniques, it can be concluded as follows:

1. Service quality variable significantly influences the purchase decision. That is, the quality of service such as employees of the BJB Bank Rawamangun Branch who are always friendly, polite and always ready to help in providing solutions to customers who come to the BJB Bank Rawamangun Branch so that customers feel happy and satisfied with the services provided.

2. Promotion variable has a significant effect on Purchasing Decisions. This means that the promotion given by the BJB Bank Rawamangun Branch is attractive so that many customers apply for new loans or apply for credit facilities (top up) at the BJB Bank Rawamangun Branch.

3. Service Quality Variable has a significant effect on Customer Loyalty. That is, good service quality, friendly and polite in serving customers and maintaining good relationships with customers will be able to cause customer loyalty to the products we sell so that customers will return to use our products again (top up)..

4. Service Quality Variable has a significant effect on Customer Loyalty through Purchasing Decisions. This means that the good and fast quality of service provided 
by BJB Bank Rawamangun Branch employees in serving the needs of customers so that customers feel satisfied and interested in using the products offered by the BJB Bank Rawamangun Branch and maintenance of the customer friendly and always maintain good relations with customers will have an impact towards the creation of a sense of customer loyalty.

5. Promotion variable has a significant effect on Customer Loyalty. That is, by implementing an attractive and appropriate promotional strategy, customers who already have facilities at the BJB Bank Rawamangun Branch are interested again in submitting a top up so that they will create a sense of customer loyalty.

6. Promotion variable has a significant effect on Customer Loyalty, through Purchasing Decisions. This means that attractive and ongoing promotions for loyal customers conducted by the BJB Bank Rawamangun Branch can also increase purchases and can lead to customer loyalty due to ongoing promotions of customers who have facilities at BJB Bank.

From the results of the study, the authors provide several suggestions that companies can consider in order to improve Purchasing Decisions and Loyalty, including:

1. The higher the quality of his service in choosing an item or service, it will increase the value of purchasing decisions. This can be done by providing friendly, fast and appropriate services in accordance with customer wishes, and can provide solutions to customer complaints and desires.

2. If the Promotion has increased it will affect the Purchase Decision. This can be done by providing attractive and ongoing promotions so that customers continue to submit top ups and loyalty to BJB Bank.

3. Service Quality has increased it will affect Customer Loyalty directly. Unlike the case if indirectly the effect that will be felt to be decreased so that it is good for the company to increase focus on each of the objectives of whether to improve the quality of service to improve purchasing decisions, and not to use the same strategy. Therefore, the good quality of service provided to consumers will have a good impact on the progress of the company.

4. Promotion has increased it will directly affect Customer Loyalty, the same as in the previous variable. If the company chooses the strategy indirectly, the effect value will decrease. This shows that promotion has a significant influence on the creation of customer loyalty and company progress

\section{REFERENCES}

[1]. Albertus, Wisnu Nugroho. 2010. Pelaksanaan Personal Selling Dalam Pengaruhnya Terhadap Keputusan Pembelian Konsumen Sepeda Motor Honda Pada Cv.Aceh Honda Motor. Universitas Komputer Indonesia, Bandung.

[2]. Alma, Buchari. 2011. Manajemen Pemasaran dan Pemasaran Jasa. Edisi Revisi.Alfabeta, Bandung.

[3]. Engel et al. 2010. Perilaku Konsumen. Edisi Keenam, Jilid 1. Binarupa Aksara, Jakarta.

[4]. Ghozali, Imam. 2013. Aplikasi Analisis Multivariate dengan Program SPSS. Edisi Ketujuh. Badan Penerbit Universitas Diponegoro, Semarang.

[5]. Hurriyati, Ratih. 2010. Bauran Pemasaran dan Loyalitas Konsumen, Alfabeta, Bandung.

[6]. Solimun, et al. 2017. Metode Statistika Multivariat, Pemodelan Persamaan Struktural (SEM), Pendekatan WarpPLS. Malang: UB Press.

[7]. Suratno; Rekarti, Endi; J. Rachbini, Didik. 2017. Peran Dalam Memediasi Pengaruh Pengetahuan Lingkungan Dan Persepsi Harga Terhadap Niat Pembelian Hijau Produk Pangan Organik. Jurnal SWOT, Vol. VII, No.2, Universitas Mercu Buana.

[8]. Syufa'ati, Vivi Laili. 2016. Pengaruh Produk, Lokasi, dan Fasilitas Terhadap Keputusan Pembelian (Studi Pada Konsumen Maccadina Yogyakarta). Universitas Islam Negeri Sunan Kalijaga.

[9]. Takeuchi, T; Nishio, C. 2000. The Qualitative Content of Television Advertising and Its Penetration: The Case in Japan. Marketing Intelligence \& Planning 18

[10]. Tamin, Ofyar Z. 2000. Perencanaan dan Permodelan Transportasi. Bandung, Indonesia: Penerbit ITB.

[11]. Thurstone, L. L. 2007. Attitudes can be measurd. American Journal of Socioloigy, 33, 529 - 54.

[12]. Tjiptono, Fandy; Chandra, Gregorius. 2012. Pemasaran Strategik. Yogyakarta:

[13]. Andi, Wijanto, Setyo Hari. 2008. Structural Equation Modeling dengan Liserl 8.8 Konsep dan Tutorial. Graha Ilmu.

[14]. Winkel, W.S. 2009. Psikologi Pengajaran. Jakarta: Gramedia.

[15]. Witherington, Cart. 2003. Psikologi Pendidikan Terjemahan Purwanto. Jakarta: Remaja Rosda Karya.

[16]. Zeithaml, Bitner, \& Gremler. 2011. Service Marketing. Edisi Keempat. Prentice Hall; exclusive right by Mc Graw - Hill. 